\title{
Carbon budget of a shallow, lagoonal estuary: Transformations and source-sink dynamics along the river-estuary-ocean continuum
}

JR Crosswell

Iris C. Anderson

Virginia Institute of Marine Science

JW Stanhope

Virginia Institute of Marine Science

B Van Dam

Mark Brush

Virginia Institute of Marine Science

See next page for additional authors

Follow this and additional works at: https://scholarworks.wm.edu/vimsarticles

Part of the Aquaculture and Fisheries Commons

\section{Recommended Citation}

Crosswell, JR; Anderson, Iris C.; Stanhope, JW; Van Dam, B; Brush, Mark; and et al., Carbon budget of a shallow, lagoonal estuary: Transformations and source-sink dynamics along the river-estuary-ocean continuum (2017). Limnology And Oceanography, 62, S29-S45.

$10.1002 /$ Ino. 10631

This Article is brought to you for free and open access by the Virginia Institute of Marine Science at W\&M ScholarWorks. It has been accepted for inclusion in VIMS Articles by an authorized administrator of W\&M ScholarWorks. For more information, please contact scholarworks@wm.edu. 
Authors

JR Crosswell, Iris C. Anderson, JW Stanhope, B Van Dam, Mark Brush, and et al. 


\title{
Carbon budget of a shallow, lagoonal estuary: Transformations and source-sink dynamics along the river-estuary-ocean continuum
}

\author{
Joseph R. Crosswell $\mathbb{D}^{1},{ }^{1,2,3 *}$ Iris C. Anderson, ${ }^{2}$ Jennifer W. Stanhope, ${ }^{2}$ Bryce Van Dam (D), ${ }^{3}$ \\ Mark J. Brush, ${ }^{2}$ Scott Ensign, ${ }^{4}$ Michael F. Piehler, ${ }^{3}$ Brent McKee, ${ }^{5}$ Molly Bost, ${ }^{5}$ Hans W. Paerl ${ }^{3}$ \\ ${ }^{1}$ CSIRO Oceans and Atmosphere, Brisbane, Queensland, Australia \\ ${ }^{2}$ Virginia Institute of Marine Science, College of William \& Mary, Gloucester Point, Virginia \\ ${ }^{3}$ Institute of Marine Sciences, University of North Carolina at Chapel Hill, Morehead City, North Carolina \\ ${ }^{4}$ Aquatic Analysis and Consulting, LLC, Morehead City, North Carolina \\ ${ }^{5}$ Department of Marine Sciences, University of North Carolina at Chapel Hill, Chapel Hill, North Carolina
}

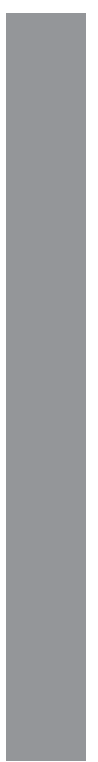

\begin{abstract}
A comprehensive carbon budget was constructed to quantify carbon flows through the freshwater-marine continuum of a temperate, microtidal estuary. We performed coordinated measurements of dissolved inorganic carbon and total organic carbon fluxes to resolve spatial variability between and along the channel and shoals and diel variability across the entire estuary for 2 yr. Net ecosystem metabolism (NEM) was the most significant control on carbon flow within estuary regions. However, metabolic rates were spatially coupled such that counteracting fluxes across the channel-shoal gradient or along the river-ocean gradient resulted in system-wide NEM that was closely in balance $\left(-3.0 \pm 3.3\right.$ to $\left.1.1 \pm 4.4 \mathrm{molC} \mathrm{m}^{-2} \mathrm{yr}^{-1}\right)$. Similarly, large diel and seasonal variability in air-water $\mathrm{CO}_{2}$ fluxes were observed during 72 spatial surveys, but these short-term variations generally cancelled out when aggregated to annual budget terms. Although atmospheric exchanges were small $\left(-0.2 \pm 0.1\right.$ to $\left.2.0 \pm 0.4 \mathrm{molC} \mathrm{m}^{-2} \mathrm{yr}^{-1}\right)$, they were subject to large errors $\left( \pm 4 \mathrm{molC} \mathrm{m}^{-2} \mathrm{yr}^{-1}\right)$ if diel variability was neglected. Internal mechanisms that maintained balanced carbon flows were strongly impacted by river discharge and were only apparent by separately quantifying channel and shoal fluxes. Notably, metabolic responses of the shoal to river forcing outweighed the responses of the channel, and the net impact was contrary to prior relationships derived from synthesis of lower-resolution carbon budgets. Our budget demonstrates that resolution of carbon fluxes at appropriate scales, including channel-shoal and diel variability, is critical to characterizing ecosystem function and the fate of carbon within the river-ocean continuum.
\end{abstract}

Estuaries are key sites of organic carbon production, respiration, and transformation. The extent of these processes and their impacts on the coastal ocean and atmosphere are influenced by a variety of natural and anthropogenic factors, including nutrient and organic carbon enrichment, land use, freshwater input, and episodic perturbation by storms (Canuel et al. 2012; Bauer et al. 2013; Crosswell et al. 2014). For example, estuaries that receive elevated rates of inorganic

*Correspondence: Joey.Crosswell@CSIRO.au

Additional Supporting Information may be found in the online version of this article.

Special Issue: Headwaters to Oceans: Ecological and Biogeochemical Contrasts Across the Aquatic Continuum

Edited by: Marguerite Xenopoulos, John A. Downing, M. Dileep Kumar, Susanne Menden-Deuer, and Maren Voss nutrient loading may produce more organic carbon than they consume and may export organic carbon to the coastal ocean (Nixon 1995; Kemp et al. 1997). Estuaries that receive carbon derived from adjacent highly-productive wetlands or from watersheds dominated by agriculture may be important sources of $\mathrm{CO}_{2}$ emissions to the atmosphere (Borges and Abril 2011; Cai 2011). Regional and global carbon budgets have generally ignored the transformations and exchanges that occur as carbon moves from the terrestrial zone downriver and across an estuary to the coastal ocean (Regnier et al. 2013a). Attempts to synthesize carbon budgets for coastal regions of North America have identified major data gaps for a number of budget terms (Najjar et al. 2012; Benway et al. 2015), including ecosystem metabolism, air-water $\mathrm{CO}_{2}$ flux, export to the ocean, and burial.

Empirical budgets provide a framework to quantify carbon flows and conceptualize the complex processes that control 
whether carbon is stored internally or exported to the ocean and atmosphere (Gordon et al. 1996). Nixon et al. (1995) used a mass-balance approach based on nutrient data and stoichiometric nutrient: carbon ratios to demonstrate that in Narragansett Bay, Rhode Island (U.S.A.) most of the internally produced organic carbon is respired within the estuary. The Land Ocean Interaction in the Coastal Zone (LOICZ) program developed a similar budget protocol that could easily be applied to existing data from estuaries worldwide (Swaney 2011). These simple budgets provided a major step toward quantifying the role of estuaries in global biogeochemical cycles, but they also had significant limitations. Stoichiometric budget methods have in some cases shown poor agreement with direct observations of carbon fluxes, and large budget uncertainties have been attributed to insufficient sampling resolution (Swaney 2011; Swaney et al. 2012). Determining what resolution is sufficient for specific research and management objectives remains one of the most critical questions in coastal ecosystem science (Swaney et al. 2012). For example, recent studies suggest that diel variability may lead to under- or overestimation of daily air-water $\mathrm{CO}_{2}$ fluxes in estuaries, but whether these errors are cumulatively significant on annual scales has yet to be quantified (Dai et al. 2009; Maher et al. 2015). Spatial heterogeneity presents an even greater obstacle. Large across-axis variability in metabolic rates has been observed between the benthic and pelagic components of shallow estuaries, but most budgets have considered only along-axis gradients or vertical gradients in the water column (Kemp et al. 1997; Gazeau et al. 2005; Eyre et al. 2011).

A present challenge is to translate observational data into functional relationships that can predict ecosystem response to future change and can be scaled to other systems. Carbon transformations in aquatic environments can be summarized as net ecosystem metabolism (NEM), the balance between production and consumption of organic carbon. A net autotrophic system generally imports inorganic nutrients and dissolved inorganic carbon (DIC) and exports or buries total organic carbon (TOC), whereas a net heterotrophic system imports TOC and exports DIC and nutrients (Nixon 1995; Boynton and Kemp 2000). Metabolism can be influenced by external and internal drivers. For example, Kemp et al. (1997) constructed a carbon budget for Chesapeake Bay and concluded that the loading ratio of inorganic nitrogen and TOC was a key control on NEM. Herrmann et al. (2015) applied this loading ratio to estimate carbon burial and export for 52 estuaries located along the east coast of the U.S. In making these estimates, the authors noted large gaps in data availability that limit evaluation of their methods and those of other regional models. Current gaps include corresponding data on both organic and inorganic carbon species and coordinated observations needed to constrain carbon exchanges between connected coastal environments (Benway et al. 2015; Testa et al. 2016).
The goal of this study was to synthesize contemporaneous data into a comprehensive carbon budget that resolves the major transformations and exchanges as carbon moves along the freshwater-marine continuum. We applied high-resolution, coordinated observations to examine how these carbon flows were balanced across spatial and temporal scales in a shallow mid-Atlantic U.S. estuary. Simultaneous water-quality mapping surveys were conducted in the channel and fringing shoals to constrain diel and seasonal variability during two consecutive years, a dry year and a wet year. Carbon inputs from the inland and lateral watersheds were directly monitored in the river and tributaries, and burial was estimated from analysis of sediment cores taken throughout the estuary. The carbon budget was constructed from empirical data using a residual carbon flow approach that focused on ecosystem connectivity.

\section{Methods}

\section{Study site}

The New River Estuary (NRE) is a shallow, microtidal system of $79 \mathrm{~km}^{2}$, located in North Carolina, U.S.A. and surrounded by Marine Corps Base Camp Lejeune $\left(631 \mathrm{~km}^{2}\right)$, with the city of Jacksonville at the head of the estuary (Fig. 1). More than 50\% of the NRE area is less than $2 \mathrm{~m}$ deep relative to mean sea level; thus, light reaches the benthic surface throughout much of the estuary and both phytoplankton and benthic microalgae are important contributors to total primary production (Hall et al. 2013; Anderson et al. 2014). The system is semi-lagoonal, consisting of a number of shallow embayments and connected to the ocean via a restricted inlet. Most freshwater input comes from the New River, which drains a $716 \mathrm{~km}^{2}$ watershed and enters at the head of the estuary. Additional freshwater input comes from small tributary creeks that span the length of the system and drain the $308 \mathrm{~km}^{2}$ lateral watershed. The NRE is seasonally stratified in the upper and middle reaches of the estuary and generally well mixed in the lower region. Tides are semidiurnal with a mean daily range of $0.43 \mathrm{~m}$ in the lower estuary and $0.17 \mathrm{~m}$ in the upper estuary (Currin 2013). The system is highly sensitive to variations in freshwater discharge; freshwater flushing times range from 1 to $150 \mathrm{~d}$ with a mean of $34 \mathrm{~d}$ (Ensign et al. 2004; Peierls et al. 2012; Hall et al. 2013).

For the purpose of developing a carbon budget, the NRE was divided into three regions, the upper, middle, and lower estuary, based on major geographic constrictions and hydrography (Fig. 1A). Estuary regions were further divided into sections to improve scaling of carbon fluxes to representative areas (Fig. 1B). Shoal and channel components were delineated in each section using the 2-m contour (mean sea level) as the boundary (Fig. 1D). The channel and shoal areas are relatively balanced in the upper and middle estuary, whereas the lower estuary is almost entirely comprised of shoal (94\%) (Supporting Information). While maximum depths in the estuary reach $5 \mathrm{~m}$, depths in the channel sections average 2.4-3 m, and the mean depth on the shoals is approximately $1 \mathrm{~m}$. The tributary watershed 
A. River and Triburtary Loading

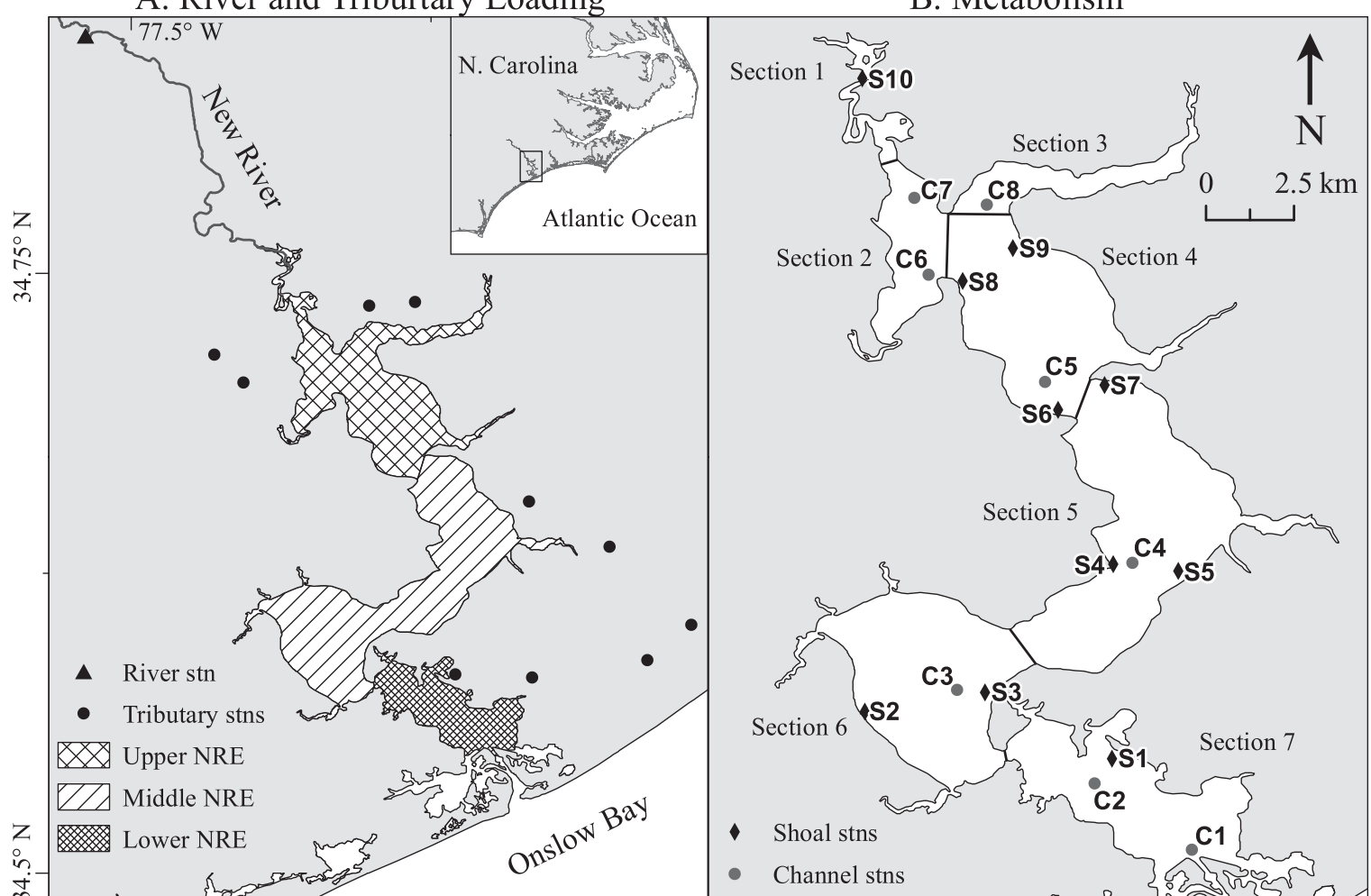

C. Air-water $\mathrm{CO}_{2}$ Flux

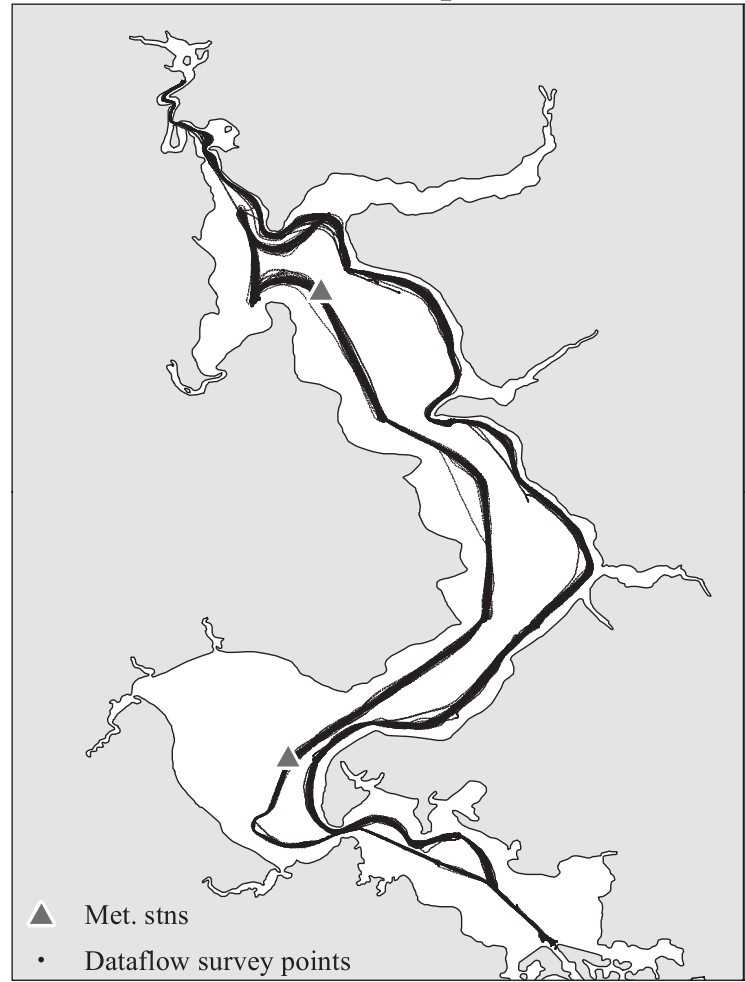

D. Burial and Bathymetry

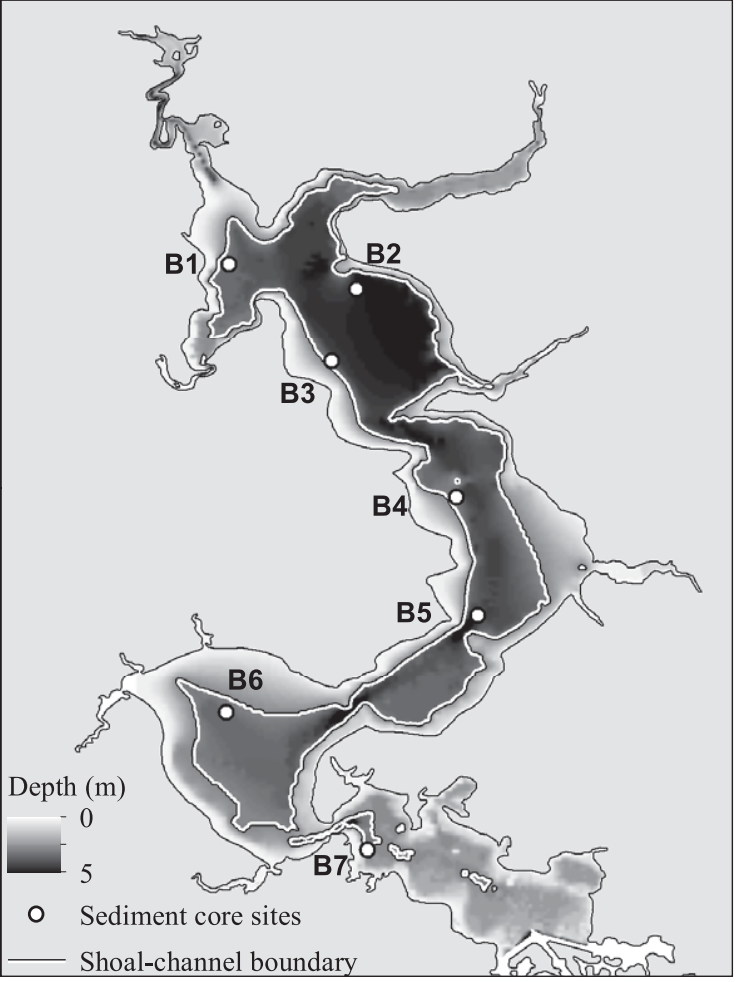

Fig. 1. Sampling sites and spatial data used in the NRE carbon budget: (A) NRE regions along with river (Gum Branch station) and tributary sampling stations used in freshwater loading estimates; (B) NRE sections along with and shoal and channel sampling stations used in metabolism estimates; (C) Meteorological stations and survey tracks from all channel and shoal surveys used in air-water $\mathrm{CO}_{2}$ flux estimates; (D) Sediment core sites used in burial estimates, and the shoal-channel boundary ( $2 \mathrm{~m}$ depth contour) applied within sections and regions. 
areas for the upper, middle, and lower estuary are $138 \mathrm{~km}^{2}$, $150 \mathrm{~km}^{2}$, and $20 \mathrm{~km}^{2}$, respectively. Most of the tidal marshes near the NRE are located outside of the system along the adjoining intra-coastal waterway, although $15 \%, 9 \%$, and $48 \%$ of the shoreline is fringed by marshes in the upper, middle, and lower regions of the estuary, respectively, (Currin et al. 2015).

\section{Carbon data collection}

Spatial surveys were conducted at bimonthly intervals from July 2013 to July 2015, where YR1 refers to the first 12 months and YR2 refers to the last 12 months. Each bimonthly sampling interval consisted of a series of three high-resolution surveys that were conducted at dawn, dusk, and the following dawn. Surveys began approximately $45 \mathrm{~min}$ prior to sunrise or sunset and required about $1.5 \mathrm{~h}$ to cover the entire NRE from the New River Inlet (Sta. C1, Fig. 1B,C) to the New River mouth at Jacksonville, North Carolina (Sta. S10). The time interval between subsequent surveys ranged from 10 to $14 \mathrm{~h}$, depending on season. Tidal influence was minor in most regions of the NRE, and differences in tidal stage between seasonal surveys were not considered. Each survey involved two research vessels conducting simultaneous transects of the estuary channel and shoal using identical high-resolution water quality mapping systems (Fig. 1C). Water was continuously pumped to a multiparameter sonde (Yellow Springs Instruments, model 6600) in a flow-thru cell (Dataflow, modified from Madden and Day 1992) and a showerhead-equilibration chamber. Equilibrated air was directed to a nondispersive infrared absorbance analyzer (Li-Cor LI-840, modified from Hales et al. 2004). Surface-water $\mathrm{pCO}_{2}$, temperature, and salinity were measured at a rate of $0.5 \mathrm{~Hz}$. Spatial data were corrected for the total system response time (average of $46 \mathrm{~s}$ ), which was measured on each individual survey. Atmospheric $\mathrm{pCO}_{2}$ was measured at the beginning and end of each survey after LI-840 calibration using a series of $\mathrm{CO}_{2}$ standard gases (120, 2000, and $5000 \mu \mathrm{atm})$.

Discrete samples for DIC were collected on each spatial survey to calculate metabolism, as described in the following sections and in the Supporting Information. Surface water DIC samples were collected at shoal stations along the eastern shore (S1, S3, S5, S7, S9, S10), and surface and bottom water DIC samples and salinity measurements were collected at all channel stations (C1-C8) (Fig 1B). An additional survey was conducted after the first dawn survey of each series in order to collect water-column profiles and discrete samples for dissolved organic carbon (DOC) and particulate organic carbon (POC) at all stations.

\section{Air-water $\mathrm{CO}_{2}$ flux}

For each spatial survey, physicochemical and $\mathrm{pCO}_{2}$ data were aggregated by NRE section into distance-weighted averages for the channel and shoal (Fig. 1B,C). Daily means were estimated for each survey series and interpolated between bimonthly survey intervals. Distance-weighted averages were also interpolated within the 24-h survey interval so that DIC-based metabolism estimates could be corrected for gas exchange, as described below. Air-water flux was calculated for each section according to Eq. 1.

$$
\text { Flux }=K_{0}\left(k_{600}\right)\left(\Delta \mathrm{pCO}_{2}\right)(\mathrm{Sc} / 600)^{-0.5}
$$

where $K_{0}$ is the solubility coefficient (Weiss 1974), $k_{600}$ is the gas exchange coefficient, $\Delta \mathrm{pCO}_{2}$ is the air-water $\mathrm{pCO}_{2}$ gradient ( $\mu \mathrm{atm}$ ), and Sc is the Schmidt number at ambient surface temperature and salinity (Wanninkhof 1992). Positive $\Delta \mathrm{pCO}_{2}$ drives efflux of $\mathrm{CO}_{2}$ from surface water to the atmosphere, whereas negative $\Delta \mathrm{pCO}_{2}$ drives uptake of atmospheric $\mathrm{CO}_{2}$. The gas transfer parameterization of Jiang et al. (2008) was selected to estimate $k_{600}$ because it represents a composite of estuarine gas exchange studies. Hourly air-water $\mathrm{CO}_{2}$ fluxes between the dawn and dusk survey intervals were calculated using the average hourly wind speed from two meteorological stations in the NRE (Fig. 1). Daily $\mathrm{CO}_{2}$ fluxes between bimonthly intervals were calculated using daily wind speeds and daily interpolation of surface water data. To approximate uncertainty, air-water fluxes were also calculated using the gas transfer parameterizations of Ho et al. (2006) and Prytherch et al. (2010). These parameterizations represent the minimum and maximum gas transfer rates that have been applied in estuaries, excluding exponential dependencies (Crosswell et al. 2014). To quantify how diel variation may influence annual flux estimates, we divided our dataset into dawn surveys and dusk surveys. We recalculated annual $\mathrm{CO}_{2}$ fluxes by separately using only the dawn data and then only the dusk data. These two additional $\mathrm{CO}_{2}$ flux estimates, which simulated scaling of data from only a single daily survey, were then compared to our more robust estimates, which were based on hourly interpolation of data between three surveys over $24 \mathrm{~h}$.

\section{Metabolism}

Gross Primary Production (GPP), ecosystem respiration $(R)$, and NEM were estimated based on the change in DIC of discrete water samples between surveys. At each station, the hourly metabolic DIC flux $(F)$ was calculated based on the difference between the dawn1-dusk $\left(F_{1}\right)$ surveys and the dusk-dawn2 $\left(F_{2}\right)$ surveys (Eq. 2 , where $\mathrm{h}_{1}=$ hours of daylight). Daily $R$, GPP, and NEM were then determined following Eqs. 3-5.

$$
\begin{gathered}
F=\Delta \mathrm{DIC}_{\mathrm{t}}-\Delta \mathrm{DIC}_{\mathrm{q}}-\Delta \mathrm{DIC}_{\mathrm{g}} \\
R=\left(F_{2}\right) \bullet 24 \\
\mathrm{GPP}=\left(F_{\mathrm{l}}-F_{2}\right) \bullet h_{1} \\
\mathrm{NEM}=\mathrm{GPP}-R
\end{gathered}
$$

where $\Delta \mathrm{DIC}_{\mathrm{t}}$ is the total change in DIC between water samples, $\Delta \mathrm{DIC}_{\mathrm{q}}$ is portion of the total DIC change that is associated with a change in salinity, and $\Delta \mathrm{DIC}_{\mathrm{g}}$ is the portion of the total DIC change that is due to air-water $\mathrm{CO}_{2}$ flux. $\Delta \mathrm{DIC}_{\mathrm{q}}$ was estimated as the change in salinity between 
consecutive water samples multiplied by the slope of the DIC: salinity regression. This slope was calculated separately for channel and shoal stations using data from the two surveys of the respective interval. The $\Delta \mathrm{DIC}_{\mathrm{q}}$ term was occasionally neglected at some stations in the upper estuary, when tidal mixing was low and the DIC: salinity relationship did not show conservative mixing. At channel stations, $F$ in the surface water $\left(F_{\mathrm{s}}\right)$ and bottom water $\left(F_{\mathrm{b}}\right)$ were integrated into a single term according to Eq. 6.

$$
F=z_{\mathrm{s}}\left(F_{\mathrm{s}}\right)+z_{\mathrm{b}}\left(F_{\mathrm{b}}\right)
$$

where $Z_{\mathrm{s}}$ is the depth of the pycnocline at the respective station, and $z_{b}$ is the average depth of the respective section minus $Z_{\mathrm{s}}$. The $\Delta \mathrm{DIC}_{\mathrm{g}}$ term was excluded from $F_{\mathrm{b}}$. The pycnocline depth was represented as the depth at which the salinity profile equaled the average of the surface and bottom salinity. If the total vertical salinity gradient at any station was less than 1.5 , then the station was considered well mixed and Eq. 2 was applied using the average of the DIC values. For each survey series, $R$, GPP, and NEM at stations within each NRE section (Supporting Information) were combined into separate sectional averages for the channel and shoal. These averages were then scaled to the three estuary regions based on area. Finally, regional values were interpolated daily between survey dates to yield annual estimates.

Daily metabolism rates based on direct measurement of DIC represent six 24-h intervals per year. A recent study of uncertainty propagation in ecosystem budgets showed that spatial and temporal variability were the dominant sources of error in scaling discrete observations to annual budget terms (Lehrter and Cebrian 2010). Following Lehrter and Cebrian (2010), we represent uncertainty as the 95\% confidence interval around the scaled annual budget terms, and we ignore measurement errors (Supporting Information). However, we take a more conservative approach than applied in most prior studies in order to account for unknown uncertainty in our open-water metabolism estimates. The annual standard error for each section was determined by including all respective sectional metabolism data (molC $\mathrm{m}^{-2} \mathrm{~d}^{-1}$ ) within that year. The metabolism data were assumed to be random samples regardless of time of year or location within the section. This approach makes no distinction between channel and shoal and accounts for uncertainty in our representation of shoals as all areas $<2 \mathrm{~m}$ depth. The 95\% confidence intervals for each section were then scaled to the annual carbon budget terms based on the channel and shoal areas.

\section{River and tributary loading}

Riverine carbon flux to the upper NRE was calculated from constituent concentrations and river discharge at the U.S. Geological Survey gaging station at Gum Branch (\#02093000; Fig. 1A). Water samples for DIC, DOC, and POC were collected at Gum Branch from March 2013 through
December 2015. Each year, at least six samples were collected during low discharge and at least six were collected during high discharge. Carbon loads ( $\left.\mathrm{Gg}-\mathrm{C} \mathrm{yr}^{-1}\right)$ were calculated by first developing a relationship between constituent concentration and discharge and then applying this relationship to daily discharge data scaled to the ungauged NRE watershed area (Supporting Information). Uncertainty in predicted loads was calculated using the 95\% confidence interval of the estimated concentration values.

Water discharge and DIC, DOC, and POC were measured at eight stations in five tributaries draining directly to the upper, middle, and lower NRE (Fig. 1A) (Piehler et al. 2013). Water samples were collected manually every other week and after rainfall events of $>2.5 \mathrm{~cm}$ in $24 \mathrm{~h}$. Sampling resolution was increased during storm events using automated water samplers (Teledyne ISCO) for DOC and POC and additional manual sampling for DIC, and discharge was measured every $30 \mathrm{~min}$. Autonomous samples were refrigerated and collected for analysis within $24 \mathrm{~h}$. Carbon yields were calculated for each sub-catchment, and the median yield was applied across the entire tributary catchment area for the NRE. Uncertainty in the predicted constituent loads to the estuary was estimated using the second lowest and second highest of the five sub-catchment constituent yields.

Flushing times were calculated using the date-specific freshwater replacement method and scaled estimates of river and tributary discharge, as described above (Alber and Sheldon 1999, Ensign et al. 2004, Peierls et al. 2012). To quantify groundwater discharge, we constructed a radon isotope $\left({ }^{222} \mathrm{Rn}\right)$ mass-balance for the NRE using surface water, bottom water, and porewater measurements from four supplemental surveys in 2015 (Supporting Information). This firstorder estimate showed that groundwater discharge was minor $(<2 \%)$, and the term was therefore neglected.

\section{Burial}

Seven cores (50 cm total depth), collected across the NRE in 2013 (Fig. 1D), were extruded and sub-sampled at 1-cm intervals within $24 \mathrm{~h}$ of collection. Organic geochemical analyses were performed via elemental analyzer-continuous flow isotope ratio mass spectrometry (Supporting Information), and the Constant Rate of Supply/Constant Flux model (Sanchez-Cabeza and Ruiz-Fernandez 2012) was applied for data interpretation. Short-term $(<5 \mathrm{yr})$ carbon accumulation rates were determined based on the ${ }^{210} \mathrm{~Pb}$ dating, dry bulk density, and percent organic carbon (Supporting Information). Burial terms applied to the 2013-2015 carbon budgets represent the mean short-term accumulation rate for each estuarine region, scaled to the respective regional area.

\section{Carbon budget}

An empirical carbon budget was developed that resolved fluxes within each NRE region. In order to conceptualize the carbon budget in terms of organic and inorganic carbon flows, DOC and POC were combined as TOC. Thus, net 


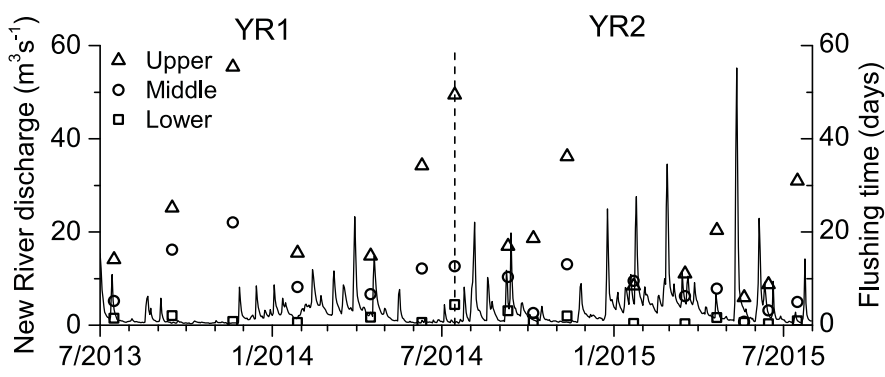

Fig. 2. New River discharge at the Gum Branch gauging station and flushing time in the NRE.

heterotrophy converted TOC to DIC and net autotrophy converted DIC to TOC. It was assumed that all major carbon fluxes were defined except advective exchanges between regions and at the estuary-ocean boundary. Beginning in the upper estuary, the advective carbon exchanges across subsequent regional boundaries were quantified based on the residual carbon flow. That is, the advective exchange at each regional boundary balanced the carbon sources and sinks in the upstream region and enabled the next residual to be estimated in the seaward region. Channel and shoal carbon fluxes were resolved as separate inputs and exports for each region. To estimate residual carbon flows, channel and shoal fluxes were integrated for each region and water-column carbon stocks were assumed to be at steady state on annual scales. This assumption was tested by scaling the DIC and TOC at each station to regional volumes following the same methods as described for metabolism. Uncertainty in the residual flows was estimated using a Monte Carlo simulation in which parameter correlations were approximated by least squares regression. Briefly, year-specific parameter distributions were sampled six times per year, corresponding to the number of survey intervals. Residual flow uncertainty was represented as the $95 \%$ confidence interval of 100,000 iterations per year. Additional carbon budget terms, including marsh deposition, shoreline erosion rainwater input, and groundwater input were estimated by scaling literature values and data from supplemental analyses. These budget terms were found to be relatively minor and were excluded from the carbon budget, but they are each tabulated and discussed in the uncertainty section.

\section{Export to ocean}

As a check on our estimates of residual carbon flows out of the estuary, net export of DIC and TOC from the NRE to Onslow Bay were computed as the product of total freshwater inflow and volume-weighted mean concentrations in the NRE, linearly interpolated between sampling dates (Supporting Information). This method corresponds to the one-dimensional approach by Officer (1980) in which there is a net downestuary, advective flow of water at all depths equal to cumulative freshwater inputs. The one-dimensional method was considered most appropriate for computing exchanges out of the NRE, given that the lower estuary is generally well mixed. This approach excludes any net exchange resulting from the tides, as we are unable to estimate the fraction of ebbing water that returns on the following tide, and the degree to which flooding water mixes with estuarine water. This approach similarly neglects short-term transport due to winds but is nevertheless useful for providing first-order estimates of exchanges when a fine-scale hydrodynamic model is not available for the system. Uncertainty in the computed carbon exports was determined using the minimum and maximum observed DIC and TOC concentrations in the estuary.

\section{Results}

\section{River and tributary loading}

The mean New River discharge at Gum Branch for YR1 $\left(2.51 \mathrm{~m}^{3} \mathrm{~s}^{-1}\right)$ and YR2 $\left(4.39 \mathrm{~m}^{3} \mathrm{~s}^{-1}\right)$ constrained approximately $60 \%$ of the annual river discharge conditions from 1950 to 2013 (mean $=3.20$, standard deviation $=1.15 \mathrm{~m}^{3}$ $\mathrm{s}^{-1}$ ). YR1 represents a relatively dry year, where the freshwater input from the river and all tributaries equaled $346 \times 10^{6}$ $\mathrm{m}^{3}$. The average flushing times for the upper, middle, and lower estuary during YR1 were 32, 12, and $2 \mathrm{~d}$, respectively (Fig. 2). YR2 represents a wet year with a total freshwater input of $465 \times 10^{6} \mathrm{~m}^{3}$ and average flushing times of 18,8 , and $2 \mathrm{~d}$ for the upper, middle, and lower estuary, respectively. The major differences in NRE hydrology between YR1 and YR2 were the input of freshwater from the inland watershed and the flushing time of the upper and middle estuary; riverine discharge at Gum Branch in YR2 was almost twice the discharge in YR1, and YR2 flushing times in the upper estuary were about half as long as in YR1 (Fig. 2). Rainwater input ranged from 89 to $125 \times 10^{6} \mathrm{~m}^{3} \mathrm{yr}^{-1}(114-159 \mathrm{~cm}$ $\mathrm{yr}^{-1}$ ) in YR1 and YR2, respectively. The estimated groundwater input was $8.2 \times 10^{6} \mathrm{~m}^{3} \mathrm{yr}^{-1}\left(10.4 \mathrm{~cm} \mathrm{yr}^{-1}\right)$, which was comparable to rates observed in the neighboring White Oak Estuary (0.6-39.4 $\mathrm{cm} \mathrm{yr}^{-1}$; Kogan and Paull 2005).

Riverine inputs of organic and inorganic carbon were approximately equal in YR1 (Table 1). As river discharge increased from YR1 to YR2, TOC accounted for a larger portion of the total riverine carbon load (Table 1; Fig. 2). Tributary loading was also a major input of DIC and TOC in YR1, accounting for about one third of the total freshwater carbon load (Table 1). Most of this input occurred in the upper and middle NRE, as the lower estuary drained only $4 \%$ of tributary catchments. During the higher discharge conditions in YR2, TOC loading was dominated by riverine discharge, representing more than $80 \%$ of the freshwater TOC input. Freshwater DIC loading was less variable between the wet and dry years because greater freshwater input was partially offset by lower DIC concentrations. Carbon loading from other freshwater sources was minor due to the low volume 
Table 1. Annual carbon budget terms $\left(10^{6} \mathrm{~g}-\mathrm{C}\right)$.

\begin{tabular}{|c|c|c|c|c|c|c|c|c|c|}
\hline & \multirow[b]{2}{*}{ Region } & \multicolumn{2}{|c|}{ YR1 } & \multicolumn{2}{|c|}{ Uncertainty bounds } & \multicolumn{2}{|c|}{ YR2 } & \multicolumn{2}{|c|}{ Uncertainty bounds } \\
\hline & & DIC & TOC & DIC & TOC & DIC & TOC & DIC & TOC \\
\hline New River & & 3359 & 3448 & $(2100-4685)$ & $(2762-4987)$ & 4857 & 7350 & $(3085-6717)$ & $(5306-10824)$ \\
\hline \multirow[t]{3}{*}{ Tributaries } & Upper & 1036 & 736 & (1291-1447) & $(430-791)$ & 1393 & 666 & $(1291-1447)$ & $(562-1712)$ \\
\hline & Middle & 1129 & 802 & $(1407-1576)$ & $(468-862)$ & 1518 & 726 & $(1407-1576)$ & $(613-1866)$ \\
\hline & Lower & 150 & 107 & $(187-210)$ & $(62-115)$ & 202 & 96 & $(187-210)$ & $(81-248)$ \\
\hline Air-water & Upper-shoal & 11 & - & $(-15,7)$ & - & 1721 & - & - & $(1050,1815)$ \\
\hline \multirow[t]{5}{*}{$\mathrm{CO}_{2}$ flux* } & Upper-channel & -261 & - & $(-186,-275)$ & - & 414 & - & - & $(218,435)$ \\
\hline & Mid-shoal & 2 & - & $(7,-2)$ & - & 110 & - & - & $(45,104)$ \\
\hline & Mid-channel & 85 & - & $(57,88)$ & - & -311 & - & - & $(-220,-338)$ \\
\hline & Lower-shoal & -1 & - & $(-3,-3)$ & - & -56 & - & - & $(-44,-63)$ \\
\hline & Lower-channel & 7 & - & $(5,7)$ & - & -2 & - & - & $(-2,-2)$ \\
\hline \multirow[t]{6}{*}{$\mathrm{NEM}^{\dagger}$} & Upper-shoal & \multicolumn{2}{|c|}{-146} & \multicolumn{2}{|c|}{$( \pm 1247)$} & \multicolumn{2}{|c|}{2644} & \multicolumn{2}{|c|}{$( \pm 1814)$} \\
\hline & Upper-channel & \multicolumn{2}{|c|}{1140} & \multicolumn{2}{|c|}{$( \pm 1161)$} & \multicolumn{2}{|c|}{56} & \multicolumn{2}{|c|}{$( \pm 1708)$} \\
\hline & Mid-shoal & \multicolumn{2}{|c|}{-761} & \multicolumn{2}{|c|}{$( \pm 2018)$} & \multicolumn{2}{|c|}{919} & \multicolumn{2}{|c|}{$( \pm 2592)$} \\
\hline & Mid-channel & \multicolumn{2}{|c|}{-3891} & \multicolumn{2}{|c|}{$( \pm 1921)$} & \multicolumn{2}{|c|}{-3021} & \multicolumn{2}{|c|}{$( \pm 2349)$} \\
\hline & Lower-shoal & \multicolumn{2}{|c|}{733} & \multicolumn{2}{|c|}{$( \pm 733)$} & \multicolumn{2}{|c|}{613} & \multicolumn{2}{|c|}{$( \pm 739)$} \\
\hline & Lower-channel & \multicolumn{2}{|c|}{55} & \multicolumn{2}{|c|}{$( \pm 50)$} & \multicolumn{2}{|c|}{-137} & \multicolumn{2}{|c|}{$( \pm 50)$} \\
\hline \multirow[t]{3}{*}{ Burial $^{\ddagger}$} & Upper & - & 928 & - & $(701-1200)$ & - & 928 & - & $(701-1200)$ \\
\hline & Middle & - & 2136 & - & (2136-10537) & - & 2136 & - & (2136-10537) \\
\hline & Lower & - & 0 & - & - & - & 0 & - & - \\
\hline
\end{tabular}

* Negative values indicate flux from air to water. Uncertainty is represented as Ho et al. (2006), Prytherch et al. (2010).

$\dagger$ Negative values indicate net autotrophy, i.e., conversion of DIC to TOC.

¥ Based on short-term ( $<5 \mathrm{yr}$ ) burial rates.

of groundwater discharge and low carbon concentrations in rainwater (Table 2).

\section{Air-water $\mathrm{CO}_{2}$ flux}

A large range in surface water $\mathrm{pCO}_{2}$ was observed during spatial surveys (11-6503 $\mu \mathrm{atm})$. The lowest regional $\Delta \mathrm{pCO}_{2}$ averages occurred during seasonal phytoplankton blooms (Fig. 3 ), where regional averages of chlorophyll $a>100 \mu \mathrm{g} \mathrm{l}^{-1}$, dissolved oxygen $>150 \%$ saturation, and $\mathrm{pH}>9$ were observed in surface waters. Diel variability in $\Delta \mathrm{pCO}_{2}$ was comparable to spatial and seasonal variability (Fig. 3). Surface waters changed from an atmospheric $\mathrm{CO}_{2}$ source at dawn to a $\mathrm{CO}_{2}$ sink at dusk during 25-60\% of the bimonthly survey series, depending on the region (Fig. 3). Temporal variability in air-water flux was primarily driven by $\Delta \mathrm{pCO}_{2}$; Hourly wind speeds showed no apparent diel or seasonal trend, and the average daily winds speeds (YR1: $4.3 \mathrm{~m} \mathrm{~s}^{-1}$, YR2: $4.2 \mathrm{~m} \mathrm{~s}^{-1}$ ) were typical for coastal regions. Flux estimates showed low sensitivity to the gas transfer parameterization used, except in the upper estuary during YR2 (Table 3).

The NRE was a minor sink for atmospheric $\mathrm{CO}_{2}$ in YR1 $\left(-0.17 \pm 0.05 \mathrm{molC} \mathrm{m}^{-2} \mathrm{yr}^{-1}\right)$ and a small $\mathrm{CO}_{2}$ source in YR2 $\left(1.99 \pm 0.43 \mathrm{molC} \mathrm{m}^{-2} \mathrm{yr}^{-1}\right)$ (Table 3; Fig. 4). The upper estuary shoal in YR2 was the only region with a large air-water $\mathrm{CO}_{2}$ flux (11.38 molC $\left.\mathrm{m}^{-2} \mathrm{yr}^{-1}\right)$, which was linked to high riverine input (Table 3). Annual air-water fluxes in all other regions were among the lowest yet observed in estuaries (Laruelle et al. 2013). Despite the relatively large range in $\Delta \mathrm{pCO}_{2}$, short-term variations at diel and seasonal scales were nearly balanced when aggregated to annual budget terms. However, scaling only the dawn survey data overestimated annual air-water fluxes by at least a factor of two, while scaling only the dusk data led to a comparable underestimation (Fig. 4).

\section{Metabolism}

The NRE was net autotrophic in YR1 (NEM of $-3.0 \pm 3.3$ molC $\mathrm{m}^{-2} \mathrm{yr}^{-1}$ ) and in near metabolic balance in YR2 (NEM of $1.1 \pm 4.4$ molC $\mathrm{m}^{-2} \mathrm{yr}^{-1}$ ) (Fig. 5). Metabolic rates in the channel were larger and more spatially variable than in the shoal. The channel showed a trend of high GPP in the upper estuary that was twice the GPP in the middle and lower estuary channel for both years (Fig. 5). The upper estuary channel was slightly net heterotrophic, whereas the middle estuary channel was strongly net autotrophic. The upper and middle estuary shoal were both net autotrophic in YR1 but net heterotrophic in YR2 (Fig. 5). In the upper estuary shoal, this transition was driven primarily by an increase in $R$, whereas the change to net heterotrophy in the middle estuary was due to a decrease in GPP. At a system-wide scale, 
Table 2. First-order estimates for terms that were excluded from the NRE carbon budget $\left(10^{6} \mathrm{~g}-\mathrm{C}\right)$.

\begin{tabular}{|c|c|c|c|c|c|}
\hline & Region & \multicolumn{2}{|c|}{ YR1 } & \multicolumn{2}{|c|}{ YR2 } \\
\hline \multirow{4}{*}{$\begin{array}{l}\text { Change in water-column } \\
\text { carbon stock }\end{array}$} & Upper-shoal & -277 & 226 & 179 & 30 \\
\hline & Upper-channel & -97 & 74 & 55 & 8 \\
\hline & Mid-shoal & -183 & 66 & 113 & -66 \\
\hline & Mid-channel & -101 & 19 & 64 & -26 \\
\hline Rainwater input* & & 26 & 297 & 26 & 297 \\
\hline Groundwater input $^{\dagger}$ & & 91 & 49 & 91 & 49 \\
\hline Shoreline erosion ${ }^{\ddagger}$ & & - & 164 & - & 164 \\
\hline Marsh deposition ${ }^{\ddagger}$ & & - & -109 & - & -109 \\
\hline
\end{tabular}

* Calculated by multiplying annual rainfall (NOAA station 723096) by the aerosol and rainwater carbon concentrations from Wozniak et al. (2011) (TOC: $248 \mu \mathrm{M}$ ) and Willey et al. (2000) (DIC: $17 \mu \mathrm{M}$ ).

† Calculated by multiplying groundwater discharge (Supporting Information) by the average carbon concentration of nearby surficial aquifers (DIC of $1397 \mu \mathrm{mol} \mathrm{kg}^{-1}$ from Gramling et al. 2003; DOC of $605 \mu \mathrm{mol} \mathrm{kg}{ }^{-1}$ from Spruill et al. 1997).

¥ Currin et al. 2015.

annual metabolism was relatively consistent between years. However, there was an apparent shift in the spatial relationships that maintain overall metabolic balance. In YR1, NEM was balanced along the longitudinal axis of the estuary. Strong net autotrophy in the middle estuary channel and shoal offset net heterotrophy in the upper and lower estuary. Both the channel and shoal were net autotrophic at the system-wide scale. In YR2, NEM was balanced by across-axis coupling of net autotrophy in the channel and net heterotrophy in the shoal (Fig. 5).

\section{Burial}

The short term $(<5 \mathrm{yr})$ burial rates in the upper and middle estuary were relatively high. Carbon burial appeared to be spatially homogenous in the upper estuary, with a mean rate of $4.85 \mathrm{molC} \mathrm{m} \mathrm{yr}^{-1}$ and a range of 3.85-6.59 molC m $\mathrm{m}^{-2} \mathrm{yr}^{-1}$. Burial rates in the middle estuary were spatially variable, ranging from 46.99 molC m${ }^{-2} \mathrm{yr}^{-1}$ at core site 4 to no net burial at core site 5 (Fig 1D; Supplemental information). Carbon burial rates in the lower estuary were negligible, as this area is nondepositional and dominated by a sandy bottom.

\section{Export to ocean}

Residual carbon flows out of the estuary were generally similar in magnitude to net exports computed from freshwater discharge and observed concentrations. Residual flows of TOC (4.53-4.89 Gg-C $\mathrm{yr}^{-1}$, Fig. 6) showed good agreement with the computed exports (3.5-6.4 Gg-C $\mathrm{yr}^{-1}$ ), and fell within the estimated uncertainty (Table 4). Similarly, the residual flow of DIC in YR2 (7.17 Gg-C yr ${ }^{-1}$, Fig. 6) was close to the computed export (9.4 Gg-C $\left.\mathrm{yr}^{-1}\right)$, and fell just outside the estimated uncertainty (Table 4 ). There was a greater discrepancy between the computed DIC export (7.3 Gg-C $\mathrm{yr}^{-1}$ ) in YR1 and the residual DIC flow (2.98 $\mathrm{Gg}_{-}{\mathrm{C} \mathrm{yr}^{-1}}^{-1}$ ) (Table 4), although both estimates show significant export of DIC that appears to be correlated with river discharge.

\section{Carbon budget}

Annual carbon budget terms are represented as mean DIC and TOC flows in Fig. 6, with uncertainty bounds in Table 1. We first summarize the carbon budget at the system-wide scale, then discuss carbon flow by region and year in the following paragraphs. Residual carbon flow for each region was always positive, indicating net transport of DIC and TOC from the river, through the estuary, and to the coastal ocean (Fig. 6). Riverine input of TOC and flushing times were the main differences in external forcing between years. Metabolism was the most significant internal control on net carbon flow. Air-water $\mathrm{CO}_{2}$ fluxes were minor except during high discharge in YR2, when surface waters transitioned from large atmospheric $\mathrm{CO}_{2}$ efflux to small $\mathrm{CO}_{2}$ uptake along the river-ocean gradient (Fig. 6). Export of TOC to Onslow Bay appeared to be consistent between years, whereas export of DIC to Onslow Bay in YR2 was about 2.5 times higher than in YR1 (Fig. 6).

\section{Upper estuary}

In YR1, the upper estuary shoal was slightly net autotrophic (Figs. 5, 6). Prior studies in the NRE have shown that during similar low-discharge conditions, nearly all of the terrestrial nutrient load was assimilated by phytoplankton near the head of the estuary (section 1, Fig. 1B) (Peierls et al. 2012; Hall et al. 2013; Paerl et al. 2013). It follows that downstream transport of phytoplankton detritus to areas with nutrient depleted conditions could explain the strong net heterotrophy observed in the upper estuary channel (Figs. 5, 6). Regardless of the pathway, at least $20 \%$ of the riverine TOC input must have been degraded in order to support the net heterotrophy in the upper 

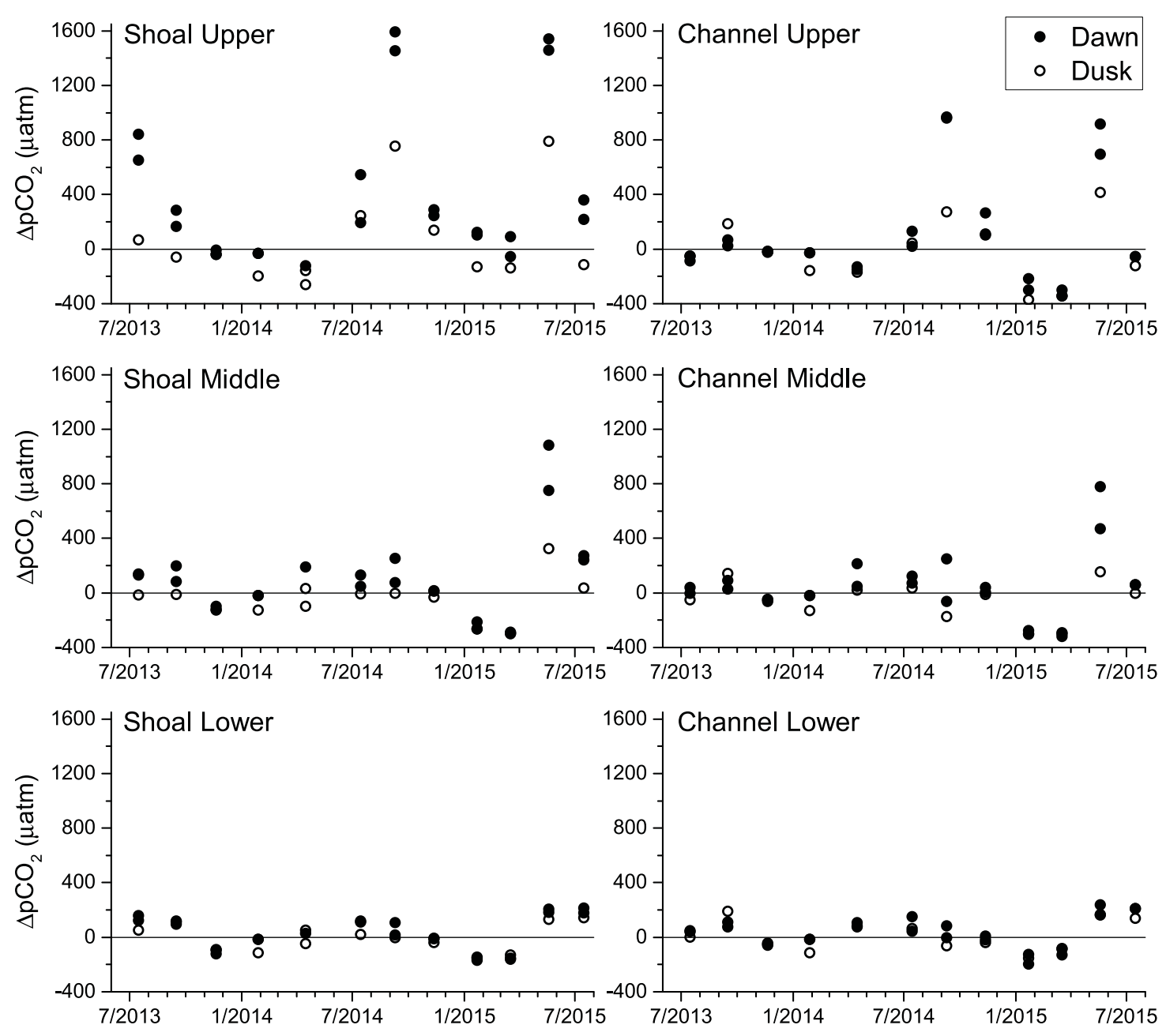

Fig. 3. Regional averages of air-water $\mathrm{pCO}_{2}$ gradients $\left(\Delta \mathrm{pCO}_{2}\right)$ that were measured via simultaneous, high-resolution spatial surveys in the shoal (left) and channel (right). Positive $\Delta \mathrm{pCO}_{2}$ drives efflux of $\mathrm{CO}_{2}$ from surface water to the atmosphere, whereas negative $\Delta \mathrm{pCO}$ drives uptake of atmospheric $\mathrm{CO}_{2}$. Error bars were omitted, as the standard error was negligible (mean $<10 \mu$ atm; maximum $<50 \mu$ atm).

estuary. The upper NRE channel was the most heterotrophic region of the estuary but also the largest sink for atmospheric $\mathrm{CO}_{2}$ (Table 1; Fig. 6). In YR2, higher riverine input had a major impact on net carbon flow in the upper estuary (Fig. 6). Strong net heterotrophy in the shoal converted approximately one third of the TOC input into DIC. Net heterotrophy in the channel decreased in YR2, but there was still significant air-water $\mathrm{CO}_{2}$ efflux. At least half of the DIC produced by net heterotrophy in the upper estuary was rapidly lost to the atmosphere, even if we assume that all excess $\mathrm{CO}_{2}$ in river water was also ventilated (Fig. 6). Burial rates in the upper estuary were relatively consistent between the three cores. The mean 5 -yr burial estimate of $0.93 \mathrm{Gg}^{-} \mathrm{C} \mathrm{yr}^{-1}$ would account for 10$20 \%$ of the freshwater TOC input.

\section{Middle estuary}

Metabolic controls dominated carbon flow in the middle estuary (Fig. 6). In YR1, strong net autotrophy in both the channel and shoal converted about $70 \%$ of the net DIC input into TOC. In YR2, the middle estuary had a less significant impact on the overall NRE carbon flow due to higher DIC input and contrasting roles of the channel and shoal (Fig. 6). Net autotrophy in the channel converted approximately $40 \%$ of the DIC input to TOC in YR2, and the channel was a sink for atmospheric $\mathrm{CO}_{2}$. About one third of these carbon exchanges in the channel were offset by net heterotrophy and $\mathrm{CO}_{2}$ efflux from the shoal (Table 1 ; Fig. 6). The middle estuary appeared to be the depositional center of the NRE, but we could not determine the relative contribution of allochthonous and autochthonous sources to TOC burial based on the carbon budget alone. Only about $20 \%$ of the freshwater TOC input was in the form of POC, which suggests that burial of autochthonous POC would be required to support the middle estuary burial term. 


\section{Lower estuary}

Net heterotrophy in the shoal was the only significant carbon exchange in the lower estuary other than advection (Fig. 6). Shoal heterotrophy may have been supported by degradation of organic matter input from the middle estuary or from surrounding marshes. Alternatively, the metabolic signal

Table 3. Air-water $\mathrm{CO}_{2}$ fluxes $\left(\operatorname{molC~} \mathrm{m}^{-2} \mathrm{yr}^{-1}\right)$.*

\begin{tabular}{|c|c|c|c|c|c|c|c|}
\hline \multirow[b]{2}{*}{ Region } & & \multicolumn{3}{|c|}{ YR1 } & \multicolumn{3}{|c|}{ YR2 } \\
\hline & & J08 & H06 & P10 & J08 & H06 & P10 \\
\hline \multirow[t]{2}{*}{ Upper } & Shoal & 0.07 & -0.10 & 0.04 & 11.38 & 6.94 & 12.00 \\
\hline & Channel & -1.43 & -1.02 & -1.51 & 2.28 & 1.20 & 2.39 \\
\hline \multirow[t]{2}{*}{ Middle } & Shoal & 0.01 & 0.03 & -0.01 & 0.47 & 0.19 & 0.44 \\
\hline & Channel & 0.38 & 0.26 & 0.39 & -1.39 & -0.98 & -1.51 \\
\hline \multirow[t]{2}{*}{ Lower } & Shoal & -0.01 & -0.02 & -0.02 & -0.40 & -0.31 & -0.45 \\
\hline & Channel & 0.76 & 0.49 & 0.79 & -0.21 & -0.18 & -0.26 \\
\hline
\end{tabular}

* J08: Jiang et al. (2008), H06: Ho et al. (2006), P10: Prytherch et al. (2010). measured by the open-water method may reflect processes that occurred within the marshes before the water is transported to the shoal (Neubauer and Anderson 2003). In either case, it appeared that the primary role of the lower estuary in the carbon budget was as a conduit for the transport of material from the middle estuary to Onslow Bay (Fig. 6).

\section{Discussion}

\section{Spatial scales of metabolic balance}

River input and tidal exchange are the main forcing mechanisms in most estuaries, and accordingly, estuaries are typically divided into river-dominated, tide-dominated, and intermediate regions for research and management applications (Regnier et al. 2013b). Indeed, river discharge appeared to be the most significant control on the NRE carbon budget, due primarily to its influence on the upper estuary (Fig. 6). However, differences in NEM between the channel and shoal were comparable to the variability observed along the riverocean axis of the estuary (Figs. 5, 6). The influence of lateral variability on the carbon budget was most significant in YR2, when counteracting fluxes in the channel and shoal acted to
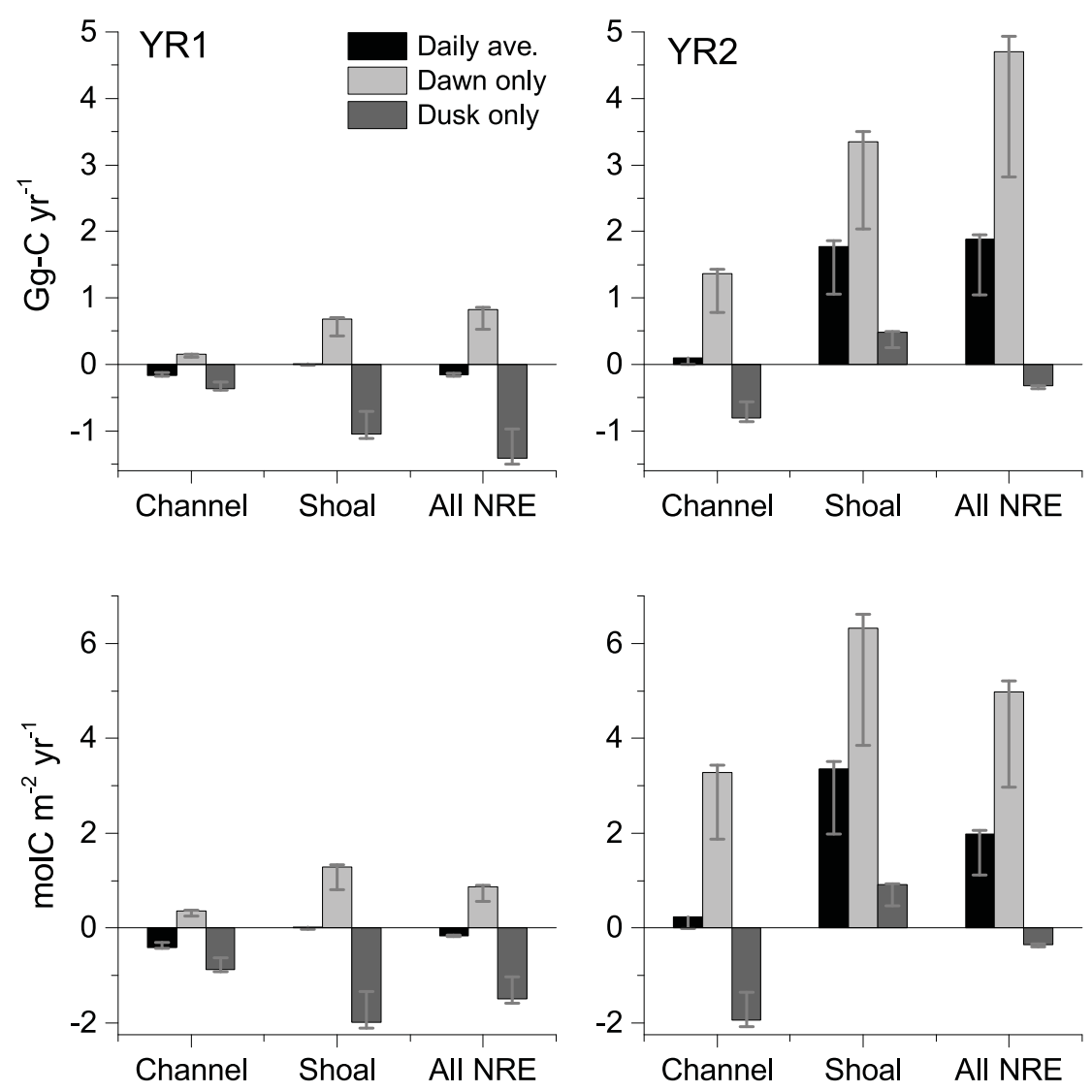

Fig. 4. Annual air-water $\mathrm{CO}_{2}$ flux estimates based on three different diel sampling resolutions: Daily ave. (black bar) = hourly interpolation of data between the dawn1, dusk, and dawn2 surveys; Dawn only (light gray bar)= scaling data from only dawn surveys; Dusk only (dark gray bar) = scaling data from only dusk surveys. Flux estimates were calculated using the jiang et al. (2008) gas transfer parameterization, with error bounds defined based on the Ho et al. (2006) and Prytherch et al. (2010) parameterizations. Only the Daily ave. fluxes were considered in the carbon budget. 

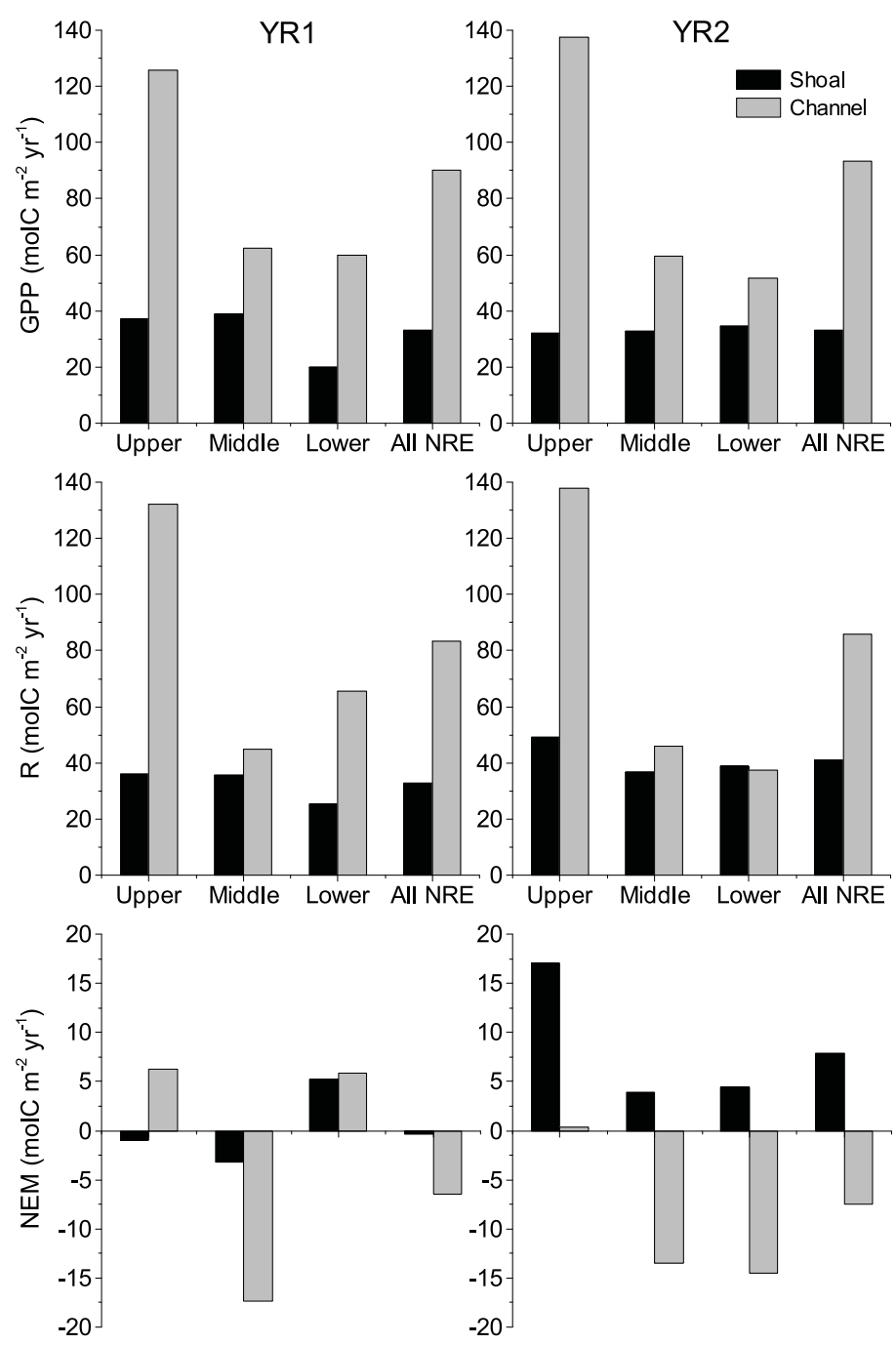

Fig. 5. GPP, ecosystem respiration (R), and NEM in the upper, middle, and lower NRE and integrated across the entire estuary (All NRE). Uncertainties in NEM estimates are listed in Table 1.

preserve metabolic balance (Figs. 5, 6). Our results are consistent with prior studies that show significant lateral variability in shallow estuaries. During two seasonal surveys in Randers Fjord, Denmark, Gazeau et al. (2005) sampled two pairs of channel and shallow sites. The authors found that NEM at the channel sites was often opposite NEM at the corresponding shallow sites. In two Australian estuaries, Maher and Eyre (2012) and Eyre et al. (2011) reported that NEM in microalgal-dominated shoals offset NEM in the channels. Kemp et al. (1997) estimated that all littoral regions in Chesapeake Bay were net autotrophic and all pelagic regions were net heterotrophic. In the aforementioned studies, channel and shoal observations were separated by days or years, during which the controls on metabolism may have changed. By collecting contemporaneous observations, we show that metabolic balance in a shallow estuary can be maintained by counteracting fluxes along the river-ocean gradient (YR1) or across the channel-shoal gradient (YR2) (Fig. 6), depending on riverine influence.

Results from the NRE were also consistent with observations from microtidal estuaries in which vertical stratification was identified as an important control on carbon cycling. Gazeau et al. (2005), Koné et al. (2009), and Crosswell et al. (2012) found evidence that $\mathrm{CO}_{2}$ generated by net heterotrophy at depth remained stored in the bottom water of microtidal systems under stratified conditions. This decoupling would explain how the upper NRE channel could be net heterotrophic and also a sink for atmospheric $\mathrm{CO}_{2}$ in YR1 (Fig. 6). The impact of destratification on carbon cycling is still not well understood in partially stratified estuaries like the NRE. Rapid carbon fluxes have been observed during tidal and wind-driven mixing events (Sin et al. 1999; Abril et al. 2004; Crosswell et al. 2014). These episodic fluxes are difficult to measure but may be a significant component of annual carbon budgets (Crosswell 2015).

Resolving carbon fluxes at the appropriate spatial scales, including differences between estuary types and between distinct habitats within estuaries, is critical to our understanding of ecosystem function. The LOICZ program compiled stoichiometry-based budgets for hundreds of estuaries and found a positive correlation between water flushing time and net heterotrophy. Based on this correlation, Smith et al. (2005) and Kemp and Testa (2011) suggested that at longer flushing times, a larger portion of imported organic matter is degraded in estuaries, thereby increasing net heterotrophy; at shorter flushing times, imported and internally produced organic matter is exported out of the system, thereby increasing net autotrophy. An opposite relationship was observed in the NRE. As flushing times decreased from YR1 to YR2, net autotrophy did increase in the channel, but this impact was outweighed by a larger shift toward net heterotrophy in the shoal (Fig. 6). Few if any of the LOICZ budgets quantified both shoal and channel exchanges. Our results, which explicitly resolve channel-shoal variability, demonstrate how traditional estuary sampling designs that only consider longitudinal variability can lead to errors in ecosystem metabolism estimates (Figs. 5, 6) and misinterpretation of key functional relationships.

\section{Temporal scales of air-water $\mathrm{CO}_{2}$ exchange}

Estuaries have been traditionally viewed as heterotrophic ecosystems with globally significant emissions of $\mathrm{CO}_{2}$ to the atmosphere (Borges and Abril 2011; Cai 2011). Our results and those of other recent flux studies indicate that estuaries are more dynamic than this view implies, demonstrating that accurate quantification of $\mathrm{CO}_{2}$ exchange requires analysis at annual, seasonal, and diel timescales. Annual $\mathrm{CO}_{2}$ fluxes in the NRE support increasing evidence that microtidal estuaries can be small sources or sinks for atmospheric 


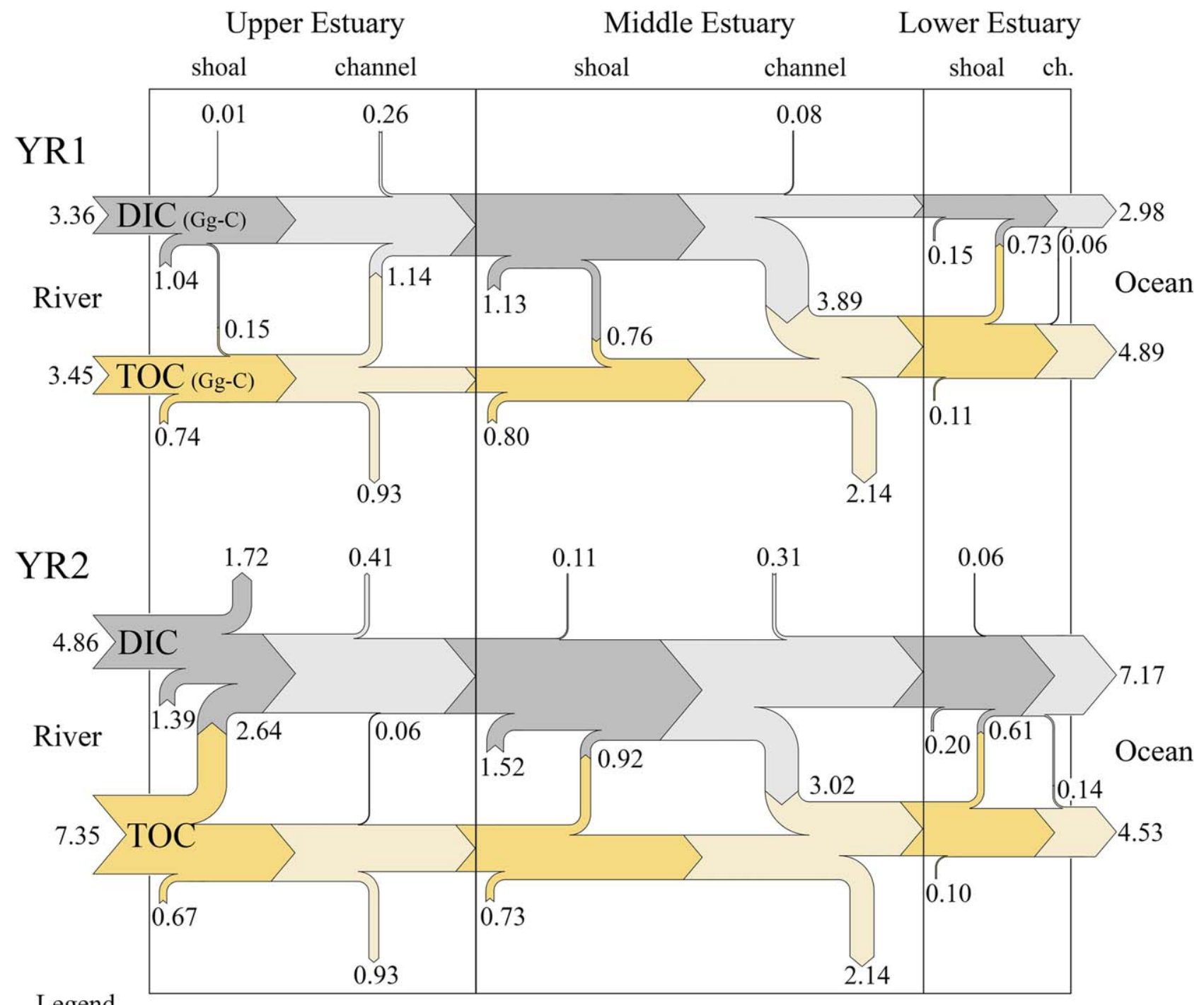

Legend

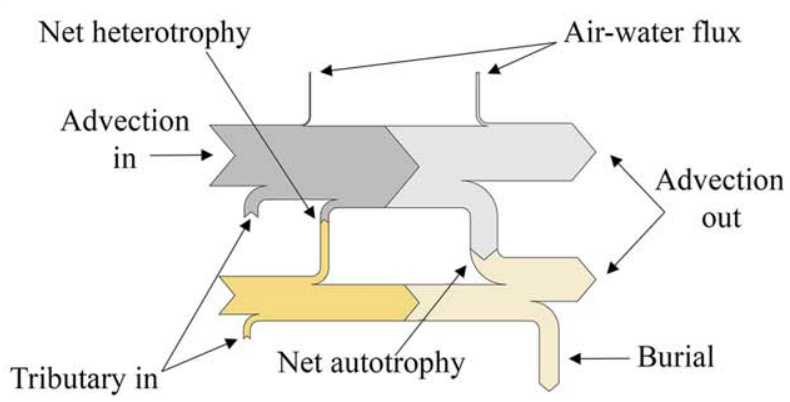

Fig. 6. Carbon flow diagram showing annual carbon budgets as DIC and TOC flows in $\mathrm{Gg}-\mathrm{C}\left(10^{9} \mathrm{~g}-\mathrm{C}\right)$. Flow width is proportional to magnitude, and the length of each region from left to right is proportional to the area of that region in the NRE. [Color figure can be viewed at wileyonlinelibrary.com]

$\mathrm{CO}_{2}$. System-wide variation in $\mathrm{CO}_{2}$ fluxes between a dry year and wet year was small $\left(-0.17-1.99 \mathrm{molC} \mathrm{m}^{-2} \mathrm{yr}^{-1}\right)$ and was comparable to the range reported by Hunt et al. 2014 in a north-Atlantic Estuary $\left(2.1-5.1 \mathrm{molC}^{-2} \mathrm{yr}^{-1}\right)$. Greater variability between annual fluxes was observed in the nearby Neuse River Estuary in response to droughts, floods, and storms (-16-4.7 molC $\mathrm{m}^{-2} \mathrm{yr}^{-1}$; Crosswell et al. 2014); however, there are currently insufficient multi-year, high resolution $\mathrm{CO}_{2}$ flux studies to gauge the magnitude of inter-annual variability. Seasonal trends in $\mathrm{CO}_{2}$ fluxes have been documented in several other estuaries along the U.S. east coast and worldwide. Estuaries have been shown to 
Table 4. Carbon export from NRE to Onslow Bay $\left(10^{9} \mathrm{~g}-\mathrm{C}\right)$. $^{*}$

\begin{tabular}{lllllll}
\hline & & & & \multicolumn{2}{c}{ Uncertainty bounds } \\
\cline { 6 - 7 } & Method & DIC & TOC & DIC & TOC \\
\hline YR1 & Computed & 7.27 & 3.50 & $(6.08-9.66)$ & $(0.85-6.20)$ \\
& Residual & 2.98 & 4.89 & $(-0.60-6.56)$ & $(0.80-8.98)$ \\
\cline { 5 - 6 } & & & & & \\
YR2 & Computed & 9.39 & 6.36 & $(7.24-13.9)$ & $(1.45-11.3)$ \\
& Residual & 7.17 & 4.53 & $(2.43-11.7)$ & $(-0.43-9.49)$ \\
\hline
\end{tabular}

* Computed exports were based on freshwater inflow and observed DIC and TOC concentrations. Residual exports were based on the sum of other carbon budget terms as described in Methods.

vary seasonally from large $\mathrm{CO}_{2}$ sources to moderate $\mathrm{CO}_{2}$ sinks due to changes in temperature, water chemistry, and biological activity (Evans et al. 2013; Hunt et al. 2014; Joesoef et al. 2015). Diel variation in $\mathrm{CO}_{2}$ fluxes has thus far been poorly constrained, with observations limited to a single season or a single sampling station (Dai et al. 2009; Maher et al. 2015; Mørk et al. 2016). Our data from 72 spatial surveys show that diel variability was comparable to seasonal variability. Prior studies in marsh- and mangrove-dominated estuaries have suggested that diel trends may be influenced by tidal pumping of DIC from surrounding wetlands (Neubauer and Anderson 2003; Maher et al. 2013). Marsh input to most of the NRE is minor on short timescales due to low tidal amplitudes and limited extent of fringing marshes (Currin et al. 2015). Thus, it is reasonable to assume that the difference between $\mathrm{pCO}_{2}$ on dawn and dusk surveys was driven by internal metabolic activity.

Most prior spatial $\mathrm{CO}_{2}$ surveys in estuaries have been conducted over hours or days, and diel variability has typically been ignored. In the NRE, we show that the time of sampling relative to diel variation can influence annual $\mathrm{CO}_{2}$ flux estimates by as much as $\pm 4 \mathrm{molC} \mathrm{m}^{-2} \mathrm{yr}^{-1}$ and can determine whether the system appears to be an atmospheric $\mathrm{CO}_{2}$ source or $\mathrm{CO}_{2}$ sink (Fig. 4). Significant diel variation in $\mathrm{pCO}_{2}$ has been reported in a few other estuary types (Dai et al. 2009; Maher et al. 2015; Mørk et al. 2016); however, more high-resolution flux observations are needed to characterize temporal trends in coastal air-water $\mathrm{CO}_{2}$ fluxes. Currently, the available data suggest that interannual variability is small in the absence of extreme events and that the time of day may be as important as the time of year when scaling $\mathrm{pCO}_{2}$ observations to annual carbon budgets.

\section{Uncertainty}

Carbon exchanges within the coastal aquatic continuum are highly variable and lead to large uncertainties that are difficult to quantify. A meaningful assessment of uncertainty is even more challenging when individual fluxes and their associated errors are integrated into system-scale budgets. (Kemp and Testa 2011). In the NRE carbon budget, we estimated advective exchanges based on the residual carbon flow between regions. This approach lends itself to a conceptual understanding of ecosystem connectivity whereby a change in carbon flux in one region may influence fluxes in other regions (Fig. 6). Exports of DIC and TOC computed from discharge and observed concentrations provided an independent check on the residual carbon flows. Both methods showed large $\left(\sim \mathrm{Gg} \mathrm{yr}^{-1}\right)$ transport of carbon from the NRE to Onslow Bay, and the mean residual flow estimates either fell within or just outside of the uncertainty bounds of the computed export, with the exception of DIC in YR1. Considering these uncertainty bounds together with those for all measured rates (Table 1), the computed exports confirm the estimated residual flows in Fig. 6. We note that the two approaches measure different processes. While the computed exports help validate the budget, only the residual method applied here can provide an estimate of estuarine trophic status and insights into the primary controls on carbon cycling, which in the NRE is internal metabolism.

Atmospheric gas exchange has previously been identified as a major uncertainty in carbon budget estimates. Our sampling methods were designed to reduce this uncertainty via high-resolution surveys that captured both diel and spatial variability across the entire estuary. The role of air-water flux in the carbon budget was minor regardless of the gas transfer parameterization used (Tables 1,3). Uncertainty in freshwater carbon loading was also relatively low ( 30\%), as input was well constrained by regular monitoring and event-based sampling in the New River and NRE tributaries (Table 1).

Uncertainty in regional metabolic rates was generally about $100 \%$; therefore, most estimates were not significantly different from zero (Table 1). This was an expected result from scaling net exchanges for cycles that are nearly balanced (Kemp et al. 1997; Eyre et al. 2011), and our estimated uncertainty was still comparable to or lower than the NEM uncertainty in other published carbon budgets (Hopkinson and Smith 2005; Kemp and Testa 2011; Maher and Eyre 2012; Herrmann et al. 2015). The open-water method for calculating metabolism requires that approximately the same mass of water is measured on dawn and dusk surveys and that non-metabolic controls on DIC are sufficiently quantified. To account for unknown errors in these assumptions, we took a conservative approach in estimating uncertainty which did not distinguish between channel and shoal. As a result, uncertainties were higher for all metabolism estimates, particularly in the upper and middle estuary (Table 1). This uncertainty is outweighed by the advantages of the open-water method in quantifying carbon budget terms, particularly compared to incubation methods (Gazeau et al. 2005). The open-water method 
integrates the active metabolic components of the system, it can be applied over relatively large spatial scales, and it does not affect the environmental conditions.

Uncertainty in burial estimates was large, mostly due to the middle estuary (Table 1). Burial rates in the upper estuary only varied by about $25 \%$ and the lower estuary showed no net burial. By contrast, burial in the middle estuary varied from zero to $46.99 \mathrm{molC} \mathrm{m}{ }^{-2} \mathrm{yr}^{-1}$, which was one of the largest fluxes by area in the NRE. The wide range of burial rates in the middle estuary may be partly due to site selection. We attempted to select coring sites that were representative of the large depositional areas in the middle estuary. Potential overestimation of burial rates due to this sampling approach was reduced by scaling only the median burial estimate (9.53 g-C m ${ }^{-2} \mathrm{yr}^{-1}$ ) in the middle estuary.

There were several potential carbon sources and sinks that were excluded from the carbon budget. We applied firstorder estimates to assess the impact of these terms on the overall budget uncertainty (Table 2). Shoreline fluxes, including erosion and deposition of TOC in marshes were small and nearly balanced. Deviation of carbon stocks from steady state conditions would account for a minor (YR1) or negligible (YR2) difference in carbon exported to the ocean (Table 2; Fig. 6). Carbon input from rainwater and groundwater was relatively insignificant (Table 2). Even if we apply the maximum groundwater discharge value $\left(39.4 \mathrm{~cm} \mathrm{yr}^{-1}\right.$, Kogan and Paull 2005) and carbon concentrations (DIC of $3256 \mu \mathrm{mol}$ $\mathrm{kg}^{-1}$ and DOC of $2800 \mu \mathrm{mol} \mathrm{kg}{ }^{-1}$, Spruill et al. 1997; Gramling et al. 2003) that have been reported in nearby estuaries, then groundwater loading of DIC and TOC would still only equal 1.0 Gg-C $\mathrm{yr}^{-1}$ each.

\section{Scaling and prediction of coastal carbon fluxes}

There have been relatively few ecosystem-scale carbon budgets in estuaries and only a handful of studies have quantified both organic and inorganic carbon fluxes (Benway et al. 2015; Testa et al. 2016). The complete carbon budget constructed in this study provides a pertinent dataset for comparison with modeled carbon fluxes along the U.S. east coast. The SPARROW (spatially referenced regression on watershed attributes) model developed by the U.S. Geological Survey estimates riverine export of TOC to estuaries across the conterminous U.S. based on watershed land use and stream photosynthesis. If we apply the SPARROW estimates of TOC yield $\left(\mathrm{kg} \mathrm{km}^{-1}\right.$ $\mathrm{yr}^{-1}$ ) (https://cida.usgs.gov/sparrow/, accessed March 2017) to the respective NRE watershed areas used in this study, the model predicts riverine TOC input of $4.96 \mathrm{Gg}^{-} \mathrm{C} \mathrm{yr}^{-1}$ and tributary input of $0.96 \mathrm{Gg}_{-} \mathrm{C} \mathrm{yr}^{-1}, 0.89 \mathrm{Gg}^{-} \mathrm{C} \mathrm{yr}^{-1}$, and $0.12 \mathrm{Gg}-\mathrm{C}$ $\mathrm{yr}^{-1}$ in the upper, middle, and lower estuary, respectively. These model estimates are in strong agreement with the average river and tributary TOC inputs for YR1 and YR2 (Table 1; Fig. 6). The modeled riverine TOC input was also remarkably similar to our residual estimates of TOC export from the NRE (Fig. 6). This might suggest that the average annual TOC load from rivers provides a reasonable approximation of TOC export from small estuaries to the coastal ocean, an assumption applied in a recent biogeochemical-circulation model of the U.S. eastern continental shelf by Cahill et al. (2016). However, our NRE budget also shows that as carbon moves along the river-ocean continuum, a significant portion of TOC can be mineralized to DIC and subsequently converted back to TOC through autotrophic production (Fig. 6). This transformation of allochthonous TOC to autochthonous TOC in estuaries represents an important biogeochemical process, as it can influence the ultimate fate of carbon that is exported to the coastal ocean.

Estuaries are diverse in terms of morphology, hydrology, and biogeochemistry, and it is challenging to scale carbon budgets between systems, even where there appear to be similarities. This is demonstrated by comparing our carbon budget to a recent modelling study by Herrmann et al. (2015) that estimated organic carbon budgets in estuaries along the entire eastern U.S. coastline. Applying the authors' rates for the NRE (Herrmann et al. [2015] supplemental; New River best estimate) to the $79 \mathrm{~km}^{2}$ NRE surface area yields a riverine TOC load of $29.6 \mathrm{Gg}-\mathrm{C} \mathrm{yr}^{-1}$, NEM of $-6.3 \mathrm{Gg}_{-} \mathrm{C} \mathrm{yr}^{-1}$, burial of 0.67

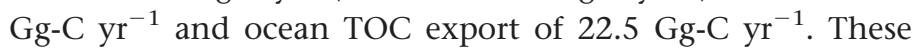
estimates differ from our budget terms by a factor of five, and we found that the NRE was net autotrophic on average rather than heterotrophic, as predicted by Herrmann et al. (2015). The two studies cover different timescales and our budget terms mostly fall within the 95\% confidence intervals from Herrmann et al. (2015), which is comparable to other site-specific studies cited by the authors. Nevertheless, the large discrepancies underscore current model limitations in representing ecosystem diversity. It is impossible to measure all relevant coastal carbon fluxes at regional and global scales. Therefore, recent efforts to assess the current state and future direction of carbon cycle research have established more practical recommendations: choose a small number of representative coastal systems, coordinate research efforts to quantify the relevant fluxes and constrain a range of environmental conditions that influence carbon cycling (Najjar et al. 2012; Benway et al. 2015). The shallow aquatic continuum of the NRE is representative of lagoonal estuaries that are broadly distributed along temperate coastlines (Laruelle et al. 2013). The observational methods applied in this study can also help identify processes that regulate carbon cycling in other estuary types. A better understanding of these controls is needed to improve models for scaling carbon fluxes and predicting how coastal ecosystems will respond to climatic and anthropogenic change.

\section{References}

Abril, G., M. V. Commarieu, D. Maro, M. Fontugne, F. Guerin, and H. Etcheber. 2004. A massive dissolved inorganic carbon release at spring tide in a highly turbid estuary. Geophys. Res. Lett. 31: L09316. doi:10.1029/2004g1019714 
Alber, M., and J. E. Sheldon. 1999. Use of a date-specific method to examine variability in the flushing times of Georgia estuaries. Estuar. Coast. Shelf Sci. 49: 469-482. doi:10.1006/ecss.1999.0515

Anderson, I. C., M. J. Brush, M. F. Piehler, C. A. Currin, J. W. Stanhope, A. R. Smyth, J. D. Maxey, and M. L. Whitehead. 2014. Impacts of climate related drivers on the benthic nutrient filter in a shallow photic estuary. Estuar. Coast. 37: S46-S62. doi:10.1007/s12237-013-9665-5

Bauer, J. E., W. Cai, P. A. Raymond, T. S. Bianchi, C. S. Hopkinson, and P. A. Regnier. 2013. The changing carbon cycle of the coastal ocean. Nature 504: 61-70. doi: 10.1038 /nature12857

Benway, H., and others. 2015. An Interdisciplinary science plan for research in North American continental margin systems, 79 p. Report of the Coastal CARbon Synthesis (CCARS) community workshop, August 19-21, 2014, Ocean Carbon and Biogeochemistry Program and North American Carbon Program.

Borges, A. V., and G. Abril. 2011. Carbon dioxide and methane dynamics in estuaries, p. 119-161. In E. Wolanski and D. McLusky [eds.], Treatise on estuarine and coastal science, v. 5: Biogeochemistry. Academic Press.

Boynton, W. R., and W. M. Kemp. 2000. Influence of river flow and nutrient loading on selected ecosystem processes and properties in Chesapeake Bay, p. 269-298. In J. Hobbie [ed.], Estuarine science: A synthetic approach to research and practice. Island Press.

Cai, W. 2011. Estuarine and coastal ocean carbon paradox: $\mathrm{CO}_{2}$ sinks or sites of terrestrial carbon incineration?. Annu. Rev. Mar. Sci. 3: 123-145. doi:10.1146/annurevmarine-120709-142723

Cahill B., Wilkin J., Fennel K., Vandemark D., and Friedrichs M. A. M. 2016. Interannual and seasonal variabilities in air-sea $\mathrm{CO} 2$ fluxes along the U.S. eastern continental shelf and their sensitivity to increasing air temperatures and variable winds. J. Geophys. Res. Biogeosci. 121: doi:10.1002/2015JG002939

Canuel, E. A., S. S. Cammer, H. A. McIntosh, and C. R. Pondell. 2012. Climate change impacts on the organic carbon cycle at the land-ocean interface. Annu. Rev Earth Planet Sci. 40: 685-711. doi:10.1146/annurev-earth-042711-105511

Crosswell, J. R. 2015. Bubble clouds in coastal waters and their role in air-water gas exchange of $\mathrm{CO}_{2}$. J. Mar. Sci. Eng. 3: 866-890. doi:10.3390/jmse3030866

Crosswell, J. R., M. S. Wetz, B. Hales, and H. W. Paerl. 2012. Air-water $\mathrm{CO}_{2}$ fluxes in the microtidal Neuse River Estuary, North Carolina. J. Geophys. Res. Oceans 117: C08017. doi:10.1029/2012JC007925

Crosswell, J. R., M. S. Wetz, B. Hales, and H. W. Paerl. 2014. Extensive $\mathrm{CO}_{2}$ emissions from shallow coastal waters during passage of Hurricane Irene (August 2011) over the Mid-Atlantic Coast of the U.S.A. Limnol. Oceanogr. 59: 1651-1665. doi:10.4319/1o.2014.59.5.165
Currin, C. A. 2013. Marsh surface elevation. Ch., 7 In Cunningham, P. [ed.], Defense Coastal/Estuarine Research Program (DCERP1) Final Monitoring Report, project SERDP RC-1413. RTI International, Research Triangle Park, NC.

Currin, C., J. Davis, L. C. Baron, A. Malhotra, and M. Fonseca. 2015. Shoreline change in the New River Estuary, North Carolina: Rates and consequences. J. Coast. Res. 31: 1069-1077. doi:10.2112/JCOASTRES-D-14-00127.1

Dai, M., Z. Lu, W. Zhai, B. Chen, Z. Cao, K. Zhou, W. Cai, and C. T. A. Chen. 2009. Diurnal variations of surface seawater pCO2 in contrasting coastal environments. Limnol. Oceanogr. 54: 735-745.

Ensign, S. H., J. N. Halls, and M. A. Mallin. 2004. Application of digital bathymetry data in an analysis of flushing times of two large estuaries. Comput. Geosci. 30: 501511. doi:10.1016/j.cageo.2004.03.015

Evans, W., B. Hales, and P. G. Strutton. 2013. $\mathrm{pCO}_{2}$ distributions and air-water $\mathrm{CO}_{2}$ fluxes in the Columbia River estuary. Estuar. Coast. Shelf Sci. 117: 260-272. doi: 10.1016/j.ecss.2012.12.003

Eyre, B. D., A. J. P. Ferguson, A. Webb, D. Maher, and J. M. Oakes. 2011. Metabolism of different benthic habitats and their contribution to the carbon budget of a shallow oligotrophic sub-tropical coastal system (southern Moreton Bay, Australia). Biogeochemistry 102: 87-110. doi: 10.1007/s10533-010-9424-7

Gazeau, F., and others. 2005. Net ecosystem metabolism in a micro-tidal estuary (Randers Fjord, Denmark): Evaluation of methods. Mar. Ecol. Prog. Ser. 301: 23-41. doi: 10.3354/meps301023

Gordon, D. C., and others. 1996. LOICZ biogeochemical modelling guidelines, v. 5. LOICZ Core Project, Netherlands Institute for Sea Research.

Gramling, C. M., D. C. McCorkle, A. E. Mulligan, and T. L. Woods. 2003. A carbon isotope method to quantify groundwater discharge at the land-sea interface. Limnol. Oceanogr. 48: 957-970. doi:10.4319/lo.2003.48.3.0957

Hales, B., D. Chipman, and T. Takahashi. 2004. High-frequency measurement of partial pressure and total concentration of carbon dioxide in seawater using microporous hydrophobic membrane contactors. Limnol. Oceanogr. Methods 2: 356-364. doi:10.4319/lom.2004. 2.356

Hall, N. S., H. W. Paerl, B. L. Peierls, A. C. Whipple, and K. L. Rossignol. 2013. Effects of climatic variability on phytoplankton biomass and community structure in the eutrophic, microtidal, New River Estuary, North Carolina, USA. Estuar. Coast. Shelf Sci. 117: 70-82. doi:10.1016/ j.ecss.2012.10.004

Herrmann, M., and others. 2015. Net ecosystem production and organic carbon balance of U.S. East Coast estuaries: A synthesis approach. Global Biogeochem. Cycles 29: 96111. doi:10.1002/2013GB004736 
Ho, D. T., C. S. Law, M. J. Smith, P. Schlosser, M. Harvey, and P. Hill. 2006. Measurements of air-sea gas exchange at high wind speeds in the Southern Ocean: Implications for global parameterizations. Geophys. Res. Lett. 33: L16611. doi:10.1029/2006GL026817

Hopkinson, C. S., and E. M. Smith. 2005. Estuarine respiration: An overview of benthic, pelagic and whole system respiration, p.122-146. In P.A. del Giorgio and P. Williams [eds.], Respiration in aquatic ecosystems. Oxford Univ. Press.

Hunt, C. W., J. E. Salisbury, and D. Vandemark. 2014. $\mathrm{CO}_{2}$ input dynamics and air-sea exchange in a large new England estuary. Estuar. Coast. 37: 1078-1091. doi: 10.1007/s12237-013-9749-2

Jiang, L. Q., W. Cai, and Y. Wang. 2008. A comparative study of carbon dioxide degassing in river- and marinedominated estuaries. Limnol. Oceanogr. 53: 2603-2615. doi:10.4319/1o.2008.53.6.2603

Joesoef, A., W. J. Huang, Y. Gao, and W. Cai. 2015. Air-water fluxes and sources of carbon dioxide in the Delaware Estuary: Spatial and seasonal variability. Biogeosci. 12: 6085-6101. doi:10.5194/bg-12-6085-2015

Kemp, W. M., E. M. Smith, M. Marvin-DiPasquale, and W. R. Boynton. 1997. Organic carbon balance and net ecosystem metabolism in Chesapeake Bay. Mar. Ecol. Prog. Ser. 150: 229-248. doi:10.3354/meps 150229

Kemp, W. M., and J. M. Testa. 2011. Metabolic balance between ecosystem production and consumption, $p$. 83-118. In E. Wolansky and D. McLusky [eds.], Treatise on estuarine and coastal science, v. 5. Academic Press.

Kogan, I., and C. K. Paull. 2005. Coastal seismic wipe-outs: Distribution controlled by pore water salinity. Mar. Geol. 217: 161-175. doi:10.1016/j.margeo.2005.02.018

Koné, Y. J. M., G. Abril, K. N. Kouadio, B. Delille, and A. V. Borges. 2009. Seasonal variability of carbon dioxide in the rivers and lagoons of Ivory Coast (West Africa). Estuar. Coast. 32: 246-260. doi:10.1007/s12237-0089121-0

Laruelle, G. G., H. H. Dürr, R. Lauerwald, J. Hartmann, C. P. Slomp, N. Goossens, and P. A. G. Regnier. 2013. Global multi-scale segmentation of continental and coastal waters from the watersheds to the continental margins. Hydrol. Earth Syst. Sci. 17: 2029-2051. doi:10.5194/hess17-2029-2013

Lehrter, J. C., and J. Cebrian. 2010. Uncertainty propagation in an ecosystem nutrient budget. Ecol. Appl. 20: 508-524. doi:10.1890/08-2222.1

Madden, C., and J. Day. 1992. An instrument system for high-speed mapping of chlorophyll a and physicochemical variables in surface waters. Estuaries 15: 421427. doi:10.2307/1352789

Maher, D. T., and B. D. Eyre. 2012. Carbon budgets for three autotrophic Australian estuaries: Implications for global estimates of the coastal air-water $\mathrm{CO}_{2}$ flux. Global
Biogeochem. Cycles 26: GB1032. doi:10.1029/ 2011GB004075

Maher, D. T., I. R. Santos, L. Golsby-Smith, J. Gleeson, and B. D. Eyre. 2013. Groundwater-derived dissolved inorganic and organic carbon exports from a mangrove tidal creek: The missing mangrove carbon sink?. Limnol. Oceanogr. 58: 475-488. doi:10.4319/1o.2013.58. 2.0475

Maher, D. T., K. Cowley, I. R. Santos, P. Macklin, and B. D. Eyre. 2015. Methane and carbon dioxide dynamics in a subtropical estuary over a diel cycle: Insights from automated in situ radioactive and stable isotope measurements. Mar. Chem. 168: 69-79. doi:10.1016/ j.marchem.2014.10.017

Mørk, E. T., M. K. Sejr, P. A. Stæhr, and L. L. Sørensen. 2016. Temporal variability of air-sea CO2 exchange in a lowemission estuary. Estuar. Coast. Shelf Sci. 176: 1-11. doi: 10.1016/j.ecss.2016.03.022

Najjar, R. G., M. A. M. Friedrichs, and W. Cai, [eds]. 2012. Report of The U.S. East Coast Carbon Cycle Synthesis Workshop, January 19-20, 2012, Ocean Carbon and Biogeochemistry Program and North American Carbon Program, 34 p. Gloucester Point, VA, USA.

Neubauer, S. C., and I. C. Anderson. 2003. Transport of dissolved inorganic carbon from a tidal freshwater marsh to the York River estuary. Limnol. Oceanogr. 48: 299-307. doi:10.4319/lo.2003.48.1.0299

Nixon, S. W. 1995. Coastal marine eutrophication: A definition, social causes, and future concerns. Ophelia 41: 199-219. doi: 10.1080/00785236.1995.10422044

Nixon, S. W., S. L. Granger, and B. L. Nowicki. 1995. An assessment of the annual mass balance of carbon, nitrogen, and phosphorus in Narragansett Bay. Biogeochemistry 31: 15-61. doi:10.1007/BF00000805

Officer, C. B. 1980. Box models revisited, p. 65-114. In P. Hamilton and K. B. MacDonald [eds.], Estuarine and wetland processes with emphasis on modeling. Plenum Press.

Paerl, H. W., N. S. Hall, B. L. Peierls, K. L. Rossignol, and A. R. Joyner. 2013. Hydrologic variability and its control of phytoplankton community structure and function in two shallow, coastal, lagoonal ecosystems: The Neuse and New River Estuaries, North Carolina, USA. Estuar. Coast. 37: 31-45. doi:10.1007/s12237-013-9686-0

Peierls, B. L., N. S. Hall, and H. W. Paerl. 2012. Non-monotonic responses of phytoplankton biomass accumulation to hydrologic variability: A comparison of two coastal plain North Carolina estuaries. Estuar. Coast. 35: 13761392. doi:10.1007/s12237-012-9547-2

Piehler, M., M. Brush, C. Tobias, and R. Noble. 2013. Quantifying and predicting watershed inputs of nutrients, sediments, and pathogens to tributary creeks on Marine Corps Base Camp Lejeune. In P. Cunningham [ed.], Chapter 6: Defense Coastal/Estuarine Research Program 
(DCERP1) Final Research Report, SERDP Project No. RC1413. RTI International, Research Triangle Park, NC.

Prytherch, J., M. J. Yelland, R. W. Pascal, B. I. Moat, I. Skjelvan, and M. A. Srokosz. 2010. Open ocean gas transfer velocity derived from long-term direct measurements of the $\mathrm{CO}_{2}$ flux. Geophys. Res. Lett. 37: L23607. doi:10.1029/2010GL045597

Regnier, P., and others. 2013a. Anthropogenic perturbation of the carbon fluxes from land to ocean. Nat. Geosci. 6: 596-607. doi:10.1038/ngeo1830

Regnier, P., S. Arndt, N. Goossens, C. Volta, G. G. Laruelle, R. Lauerwald, and J. Hartmann. 2013b. Modelling estuarine biogeochemical dynamics: From the local to the global scale. Aquat. Geochem. 19: 591-626. doi:10.1007/ s10498-013-9218-3

Sanchez-Cabeza, J. A., and A. C. Ruiz-Fernandez. 2012. ${ }^{210} \mathrm{~Pb}$ sediment radiochronology: An integrated formulation and classification of dating models. Geochim. Cosmochim. Acta 82: 183-200. doi:10.1016/j.gca.2010.12.024

Sin, Y., R. L. Wetzel, and I. C. Anderson. 1999. Spatial and temporal characteristics of nutrient and phytoplankton dynamics in the York River. Estuaries 22: 260-275. doi: $10.2307 / 1352982$

Smith, S., and others. 2005. C, N, P fluxes in the coastal zone, p. 95-143. In C. J. Crossland., and others [eds.], Coastal fluxes in the anthropocene. Springer.

Spruill, T. B., J. L. Eimers, and A. E. Morey. 1997. Nitratenitrogen concentrations in shallow ground water of the coastal plain of the Albemarle-Pamlico drainage study unit, North Carolina and Virginia. Fact Sheet FS-241-96. Reston (VA): US Geological Survey.

Swaney, D. P. 2011. Biogeochemical budgeting in estuaries, p. 343-359. In E. Wolanski and D. McLusky [eds.], Treatise on estuarine and coastal science, v. 5: Biogeochemistry. Academic Press.

Swaney, D. P., and others. 2012. Five critical questions of scale for the coastal zone. Estuar. Coast. Shelf Sci. 96: 921. doi:10.1016/j.ecss.2011.04.010

Testa, J. M., W. M. Kemp, L. A. Harris, R. J. Woodland, and W. R. Boynton. 2016. Challenges and directions for the advancement of estuarine ecosystem science. Ecosystems 1-9. doi:10.1007/s10021-016-0004-0

Wanninkhof, R. 1992. Relationship between wind speed and gas exchange. J. Geophys. Res. 97: 7373-7382. doi: 10.1029/92JC00188

Weiss, R. 1974. Carbon dioxide in water and seawater: The solubility of a non-ideal gas. Mar. Chem. 2: 203-215. doi: 10.1016/0304-4203(74)90015-2

Willey, J. D., R. J. Kieber, M. S. Eyman, and G. B. Avery. Jr. 2000. Rainwater dissolved organic carbon: Concentrations and global flux. Global Biogeochem. Cycles 14: 139-148. doi:10.1029/1999GB900036

Wozniak, A. S., J. E. Bauer, and R. M. Dickhut. 2011. Fossil and contemporary aerosol particulate organic carbon in the eastern United States: Implications for deposition and inputs to watersheds. Global Biogeochem. Cycles 25: GB2013. doi:10.1029/2010GB003855

\section{Acknowledgments}

This work would not have been possible without the assistance of J. Braddy, H. Walker, B. Abare, K. Rossignol, R. Sloup and all those at VIMS and UNC who provided support in the field and lab. We are also thankful to S. Cohen of NAVFAC and the Camp Lejeune Environmental Management Division staff. This research was conducted under the Defense Coastal/Estuarine Research Program (DCERP), funded by the Strategic Environmental Research and Development Program (SERDP). Views, opinions, and/or findings contained in this report are those of the authors and should not be construed as an official U.S. Department of Defense position or decision unless so designated by other official documentation. Raw data used in this study and other DCERP data products are accessible via the DCERP Data and Information Management System (https://dcerp.rti.org/\#/data-portal).

\section{Conflict of Interest}

None declared.
Submitted 08 November 2016 Revised 05 May 2017; 07 June 2017 Accepted 14 June 2017

Associate editor: Marguerite Xenopoulos 